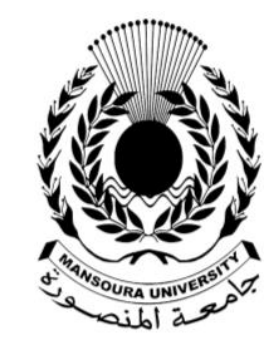

جامعة المنصـورة المعانية

$$
\text { كليـة الآداب }
$$

\title{
الحوار الداخلي في رواية ظل الأفعى في ضوء النظرية البنيوية.
}

\author{
إعـــداد \\ دكتور / السيد نعيم شريف ناصر \\ مدرس نظرية الآداب \\ كلية الآداب- جامعة المنصورة
}

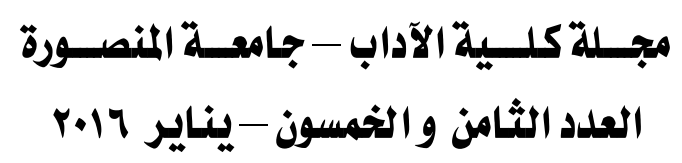




\section{العوار الدافلي في رواية ظل الأفعرى \\ في ضوء النظرية البنيوية.}

\section{د السيد نعيم شريف ناصر}

سكونيته بغض النظر عن علاقتـهـ بصـاحبه أو

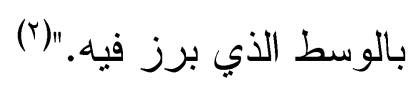

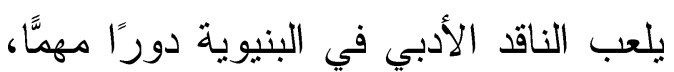

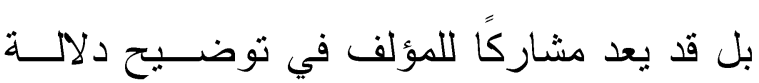

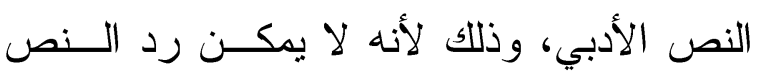

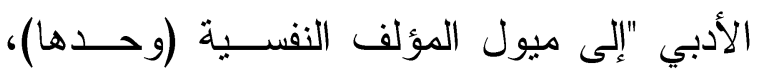

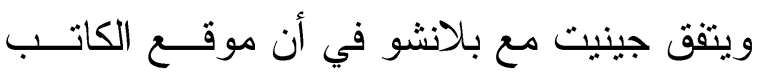
بالنسبة إلى النص الأدبي هو موقع اختباء وستر ،

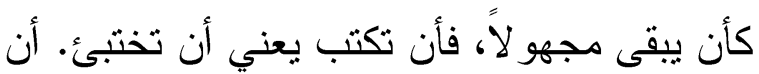

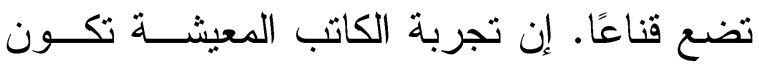

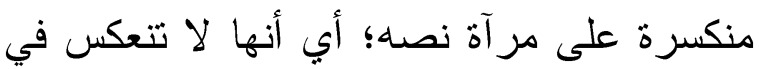

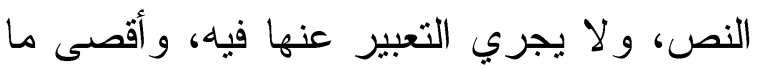

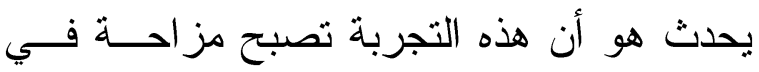

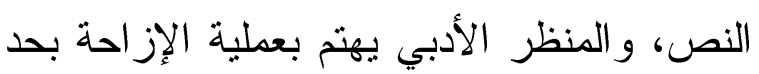

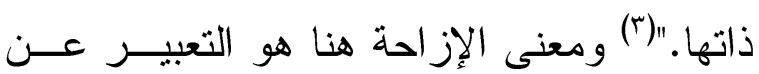

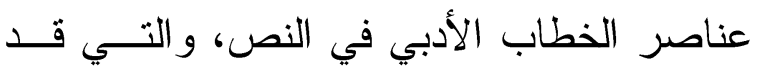

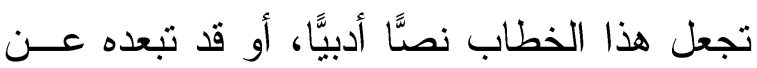
أن يكون نصنًا أدبيًّا في الأساس.

وقد يبدو أن اعتماد البنيوية على اللسانيات في تحليل النص الأدبي أمر معقول، لكن تحليل

(r) حميد لحمداني، بنية النص السردي من منظور النقا

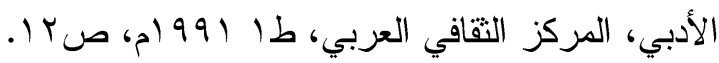

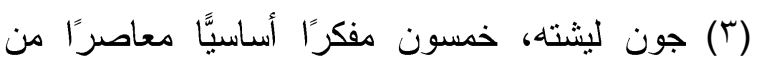
البنيوية إلى ما بعد الحداثة، ت/ فاتن البئه البستاني،

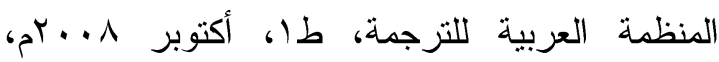

تتعامل النظرية البنيوية مع النص الأدبـي

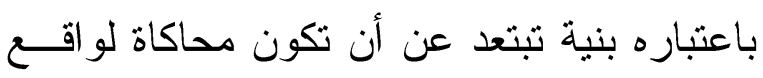
خارجي؛ (سياســي - اجتمــاعي - اقتصــادي).

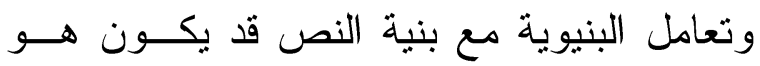

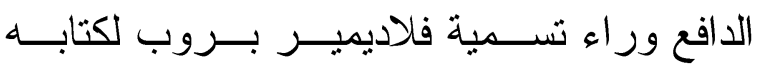
بـ"مورفولوجيا القصة"، وذللك لأن مورفولوجيا بـانيا تعني "دراسة الأشكال، وفي علم النبات، فإنهـا

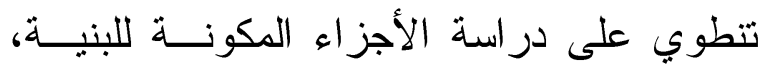
و علاقة هذه الأجز اء بعضها ببعض، وعلاقة كل لأل

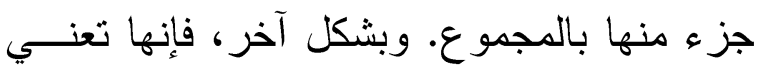
در اسة بنبة النبتة."( ) (1)

هذا التعامل مع النص الأدبي بوصفه بنيــة

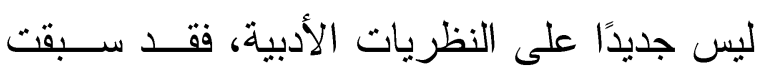

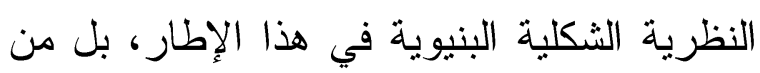

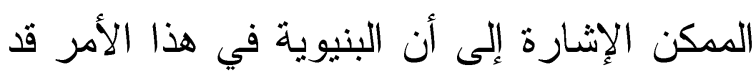

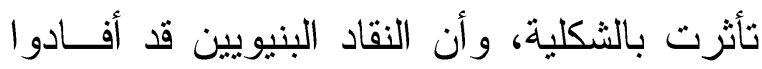
"كثيرًا من أبحاث الشكلانيين، و أخذو ا مستعينين في ذلك بالمبادئ اللسانية السوسيرية التي تميـز

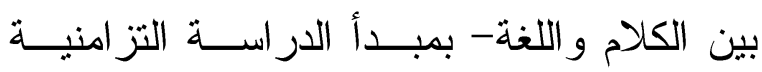

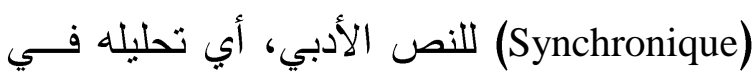
(1) فلاديمير بروب، مورفولوجيا القصة وتحولات القصص العجيية، ت/ عبد الكريم حسن- سميرة بن

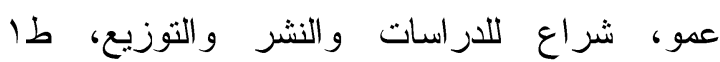
( ) 
يشاركه القارئ في عملية الاستناج، و لإحساسه بأهمية أن تتوجه الشخصية مباشرة إلى القـارئ بضمير "أنا" الذي يتخذ دور البطل يحكي قصته، و التي قد تأخذ أيضًا "أنـا" الثــــاهد عنـــدما تقــدِّم الشخصية صاحبة المنولوج شخصــية أخــرى غائبة عن الأحداث، وذلك بعد أن كان الضــمير "هو" السارد العليم هو المتحكم في عملية السرد، فــ"كل تخييل سردي هو بطبيعته سريع، ذلك أنه لا يستطيع، وهو يبني عالمًا يعج بالشخصــيات و الأحداث أن يقول كل شيء عن هذا العالم. إنه

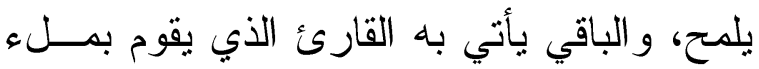

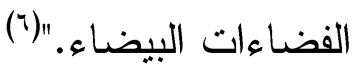
إن التحليل البنيوي لم يعــــ ينظـــر إلــى

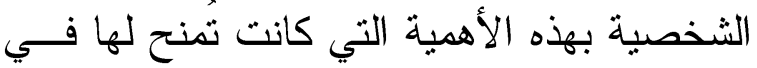

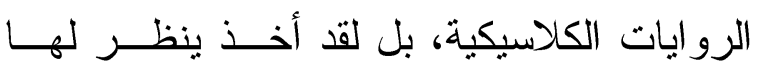
باعتبار ها "عامل متو اليات من الأفعال الخاصـــة بها (غش- إغراء)، وعنــدما تتضــمن نفـس المتو الية شخصيتين ( وتلك هي الحالة العاديــة)،

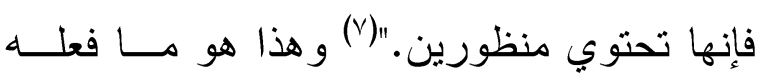
سارد "ظل الأفعىى" عنــدما جعــل الحـــوار ات الداخلية تدور في فلك شخصيتين رئيستين فـي الحدث القصصي، فقدَّم بذلك للقارئ الحدث مــن وجهتي نظر متعارضتين، وتــرك لـــه مهمـــة
السرد يبدأ مما بعد الجملة، فمن وجهــة نظـــر اللسانيات "فإن الخطاب لا يخلو مما يوجد فـي الجملة؛ فالجملة.... هي أصـــز مقطــع ممثـلـ

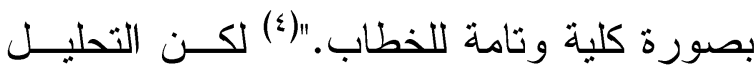
البنيوي للنص الأدبي كما وضحه رو لان بــارت قد يخضع لثلاثة مستويات، وذللك عندما أشــار إلى أننا "نقترح أن نميز في المؤلَّف السردي بين ثلاثة مستويات للوصف هي: مستوى الوظـــائف (بالمعنى التي تحمله الكلمــة لــدى بــروب)... ومستوى الأفعال (بالمعنى التي تحمله الكلمة لدى غريماس عنــدما يتحــدث عــن الشخصــيات باعتبار ها عو امل)، ومستوى السرد (وهو يشــبه إلى حد ما مستوى الخطاب لدى تـودوروف)، و علينا أن نتذكر أن هذه المستويات الثلاثة نرتبط

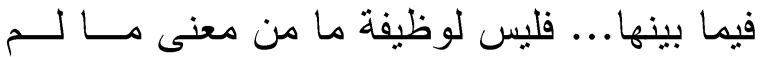
تجد لها مكاناً في الفعل العام لعامل مـــا، وهــــا الفعل يستمد معناه الأخير من كونه مسرودًا إلى خطاب له سننه الخاصة."(0)

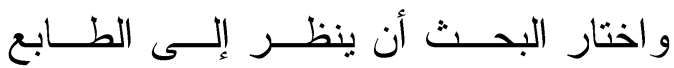
الوظيفي في تحليل الوحدات السردية لرواية "ظل الأفحى"، وذلك بالنظر إلى الوظيفة التي يقوم بها

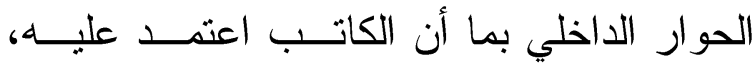
و استغنى به عن الحوار الخارجي، لرغبته في أن

(§) مجموعة من المؤلفين، طر ائق تحليل السرد الأدبي،

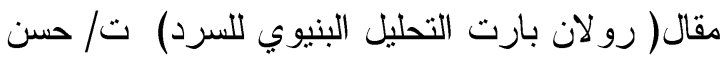
بحراوي، بشير القمري منشورات اتحاد كتاب

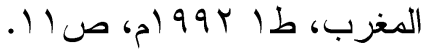
(0) مجموعة من المؤلفين، طر ائق تحليل السرد الأدبي، مقال( رو لان بارت التحليل البنيوي للسرد)، صع الـ لـ 
نجد الشخصية مثلا تزدد أي كلمة تعبر بها عن غضبها من هذه السخرية، وبخاصة أن مفردات

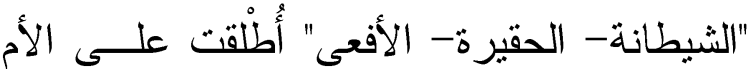
في الجزء الأول من الرواية.

\section{الحوار الخارجي والحوار اللداخلي:}

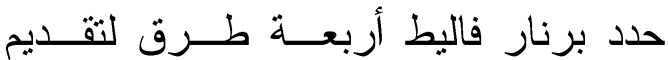
الثخصية إلى القارئ بطريقــة غيــر مباشــرة أجملها في هذا الجدول:

\begin{tabular}{|c|c|c|c|}
\hline المونولوج & الحوار & المحكي & تصوير \\
\hline 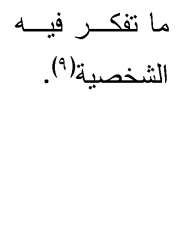 & 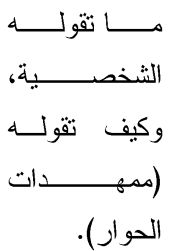 & 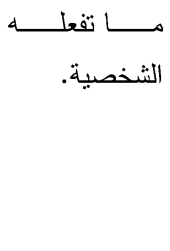 & ذأوطو الثيوغرافي \\
\hline
\end{tabular}

فجعل بهذا الحوار والحوار الــداخلي مـــن ضمن الطرق غير المباشرة في تقديم الشخصية، و إذا كان الحوار هو "عرض (در امــاتيكي فـي

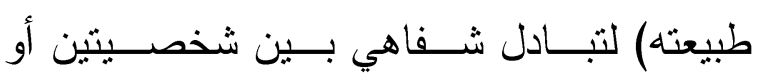
أكثر."(·) فإن الحوار الداخلي هو "خطاب طويل تفضي به شخصــية واحــدة (ولـــس موجهً

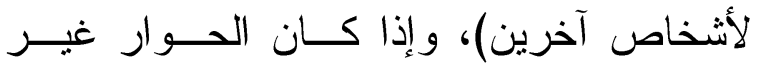
منطوق (أي مؤلفًا من التفكير ذي الصوت العالي

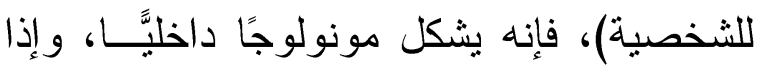

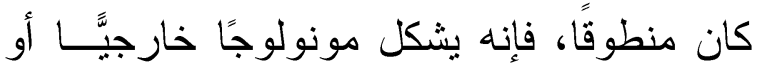
مناجاة للنفس."(1)

(9) برنار فاليط، النص الروائي تقنيات ومناهج، ت/

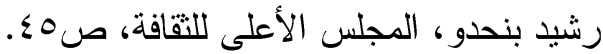

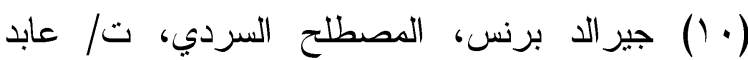

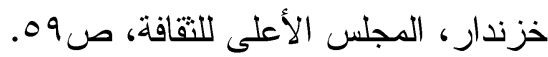

الوصول إلى العلاقات بين عناصــر الوحــدات السردية لهذه الحو ار ات الداخلية.

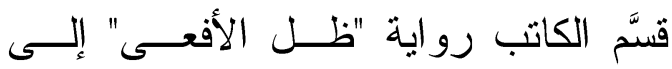
قسمين: الجزء الأول من الرواية، و عدد صفحاته و احد وتسعون صفحة من القطع المتوسط عبارة عن حدث يدور بين زوج وزوجته مــن ســارد عليم، في مدة زمنية لا تزيد عن ســـ عشــرة ساعة، تبدأ في الثالثة عصرًا عند رجوع الزوج من العمل، وتتتهي بهروب الزوجة مــن البيــــ عند الفجر أو كما يقول: "إنها السادسة صباحًا أو السابعة، أو أي ساعة كانت"(^) بعد صر اع بــين الزوجين، ومحاولة الزوج منعها من الهرب. يبدأ بعد هذا الجزء الثاني من الرواية، وهو الجزء الخاص برسائل الأم، التي توجهها إلـى ابنتها التي ابتعدت عنها لمدة ثلاتــة و عشـــرين عامًا، ويرى البحث أن الرسائل تحمـلـل وجهـــة نظر الأم وحدها. و عدد صفحاته سبعون صفحة من القطع المتوسط، وهو جزء يزعم البحث أنه يكاد ينفصل عن الجزء السابق، فلا يوجد رابـط بينهما إلا شخصــية الأم المرســلة للرســائل، وشخصبة الزوجة (الابنة) المستقبلة، و الدليل أنه عندما سخرت الأم من ديكـور شــقة الابنــة، وأرجعته إلى ذوق زوجها السيء، قائلة: "لابد أن الن الن الن زوجلك هو الذي اختاره، فلا طراز يجمع بــين

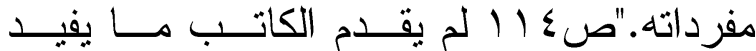
امتعاض شخصبة عبده من هذه السخرية، فلــم

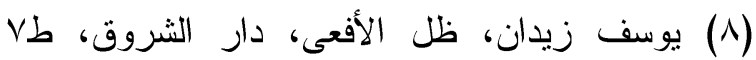
11 ( آم، ص99، سيكتب البحث بعد ذلك رقم الصفحة 
حد ما حالة النوتز الذي تعيشه شخصية الزوجة، لأن "من شأن الشخصيات الموجودة في ظروف متوتزة أو خطيرة أن تتحدث بإيجاز أكثر مــن

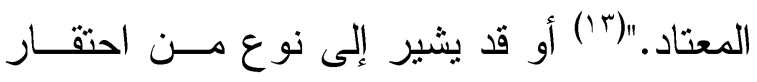
الزوجة لزوجها.

إن حوارات الرواية تسير على خطى هذا الحوار؛ هناك محاولة من الزوج لإجر اء الحوار، و الزوجة تتهيه بكلمة، ومثاله هذا الحــوار فـي

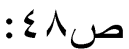
"-تعال نخر ج نروح نتعشى برة. -شكرًا -أنا جعان فعلاً.. نروح المطعم إياه. -أكلك جاهز في المطبخ." بل قد يصل الأمر بلغة الحوار ألا يجد منها

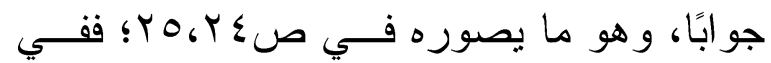
أثثاء علاقة جنسية بينهما تعيش الزوجــة فـي حوار داخلي تتهيه بصوت مســموع: "'- مامــــا خديني." فيكون جو اب عبده "- ثقصدي إيه بكلامك،

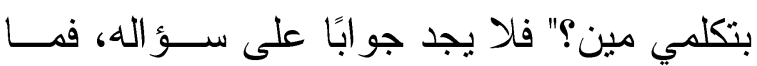
يكون منه إلا أن يتوسل إليها ألا تتهي العلاقـــة،

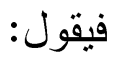

"- أرجوكِ يـــا حبيبتــي دقيقــة و احسـدة

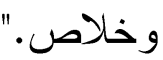
وكانت قد دفعته عنها في لحظة الجمـــاع، وهنا يُظهر التوسل لها أن تتركه دقيقة واحدة كي ينهي ما بدأه.
اعتمد سارد رواية "ظل الأفهـى بشـــل أساسي على أسلوب الحوار الداخلي فــي تقــديم شخصيات الحــدث، أو بــالأحرى فـــي تقـــيم شخصيتي الزوج و الزوجة، بمــــا أن الحـــوارات

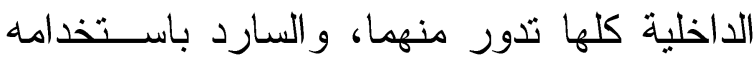

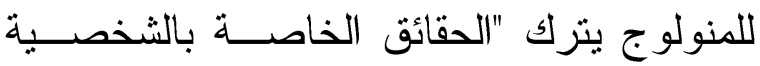
تظهر تدريجيَّا، وتتنوع أو تتنقل مباشــرة عــن طريق الحدث و الكلام"(r'). وقد يكون من المالئم عرض بعض النماذج للحوار ات الخارجية، لتوضيح هذا؛ فأول حــوار يدور بين الزوجين نجده في (صع (): ويــور على هذا الإطار:

"-إيه اللي سمعته منك ده؟ وبعــدين، إيــهـ

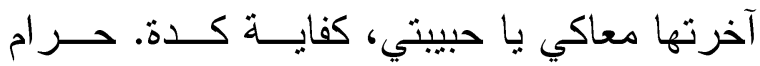
عليكي. أنا بحبك، ومخلص.

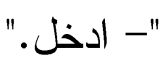

ونـلاحظ من هذا الحوار أن الزوج "عبــده"

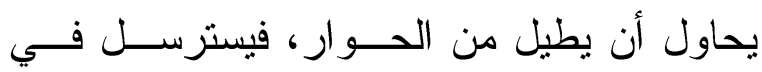
الخطاب، ويعرضه في ثماني عشرة كلمة، أمـــا الزوجة، فتقتصد في الخطاب، فترد بكلمة و احدة، وكأنها تريد إنهاء هذا الحوار سريعًا، وهو مـــا يحدث، فنجد السارد العليم ينهي الحوار، بتذخله قائلاً: "لم يستطع أن يكمل. كان ينوي أن يعلــو

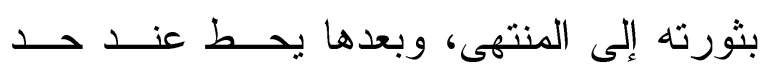
التوسل، ثم يرسو على شط الـــكريات الحلـــوة بينهما." فهذا الحوار الذي يعد نموذجًّــا لبــاقي الحوارات الخارجية في الرواية قد يوضح إلـى

(Y Y Y ( ديفيد لودج، الفن الروائي، ت/ماهر البطوطي،

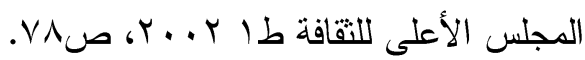


للأفكار العاطفية أن تعلق على أحــــاث القصـــة

و وتغنبها." (1)

و الحوار السابق يشــير إلــى أن الزوجـــة

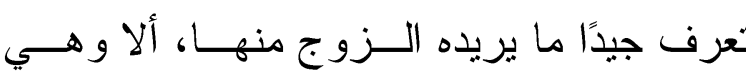

الممارسة الجنسية فقط، وهي هنا ترفض هــذه

الرغبة منه، وهو ما قد يوضح أزمة الحدث.

وقد يوضح الحوار الخارجي فـي صاءع

هذه الصورة بشكل كبير، فبعد أطول حــوار ات

الرواية بين الجد و الزوجة. هذا الحـــوار الــذي

استمر بينهما من صع ז: ص اء؛، وبعد أن ينهي

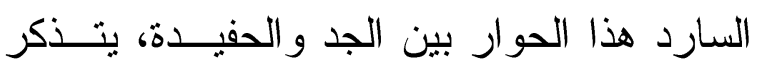
عبده أنه "استطال فترة سكوته، فدعته نفسه ليثبت حضور هأي شيء يقوله... فقال: - يا حبينتي مش كدة بالر احة شوية. - إنت تسكت خالص.. خالص." وهو حوار خارجي يؤكد هذه القــوة مـــن الزوجة، وقد يفيد نظرة الاستعلاء التي تتظر بها الزوجة تجاه زوجها. كما قد تبرز هذه العلاقــة المفتقدة بين الزوجين. ويؤكد الحوار في صه ع هذه القوة:

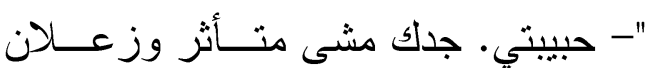
منك. كلمبه بكرة الصبح. - ممكن تخليك في نفسك، كفايــة اللـي

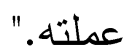
يزعم البحث أن عدم اعتماد الكاتب علـى الحوار الخارجي، باعتباره وسيلة فعالــة مــن إنـ طرق تقديم الشخصية، يرجع إلى هذا الإحساس

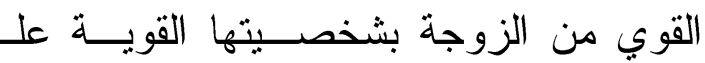

وفي أحيان أخرى قد يصل الأمر بالزوجة

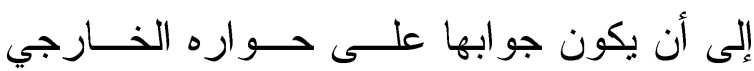
بحوار داخلي منها، وهو ما يظهر في الصفحات

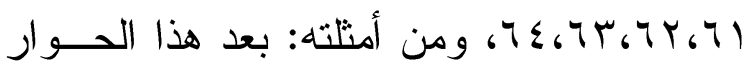

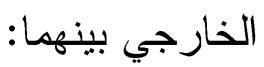

"-حبينتي. ليه بتحبي المزيكا دي؟ - لأنها صورة حياتنا. - آه!" صטים تبدأ الزوجة في حوارها الــــاخلي، وفيــــ توضح مدى جهل عبده، وأن هذه الأمور أعمق مما يظن. تقول: "آه منك، متى ستفهم أن الأمور أعمق مما تظن وتحب وتتمنى. إنك تتمنى الآن

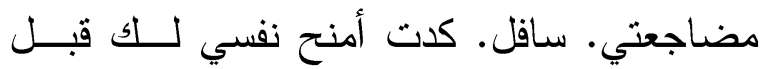
ساعتين، ثم اكتشفت بعدها بدقائق أنك وشيت بي لجدي. ماذا كنت تتوقع؟ لي عنقي! لن تقدر، ولن يقدر جدي أو غيره على ذلك. ما عاد عنقي بيد

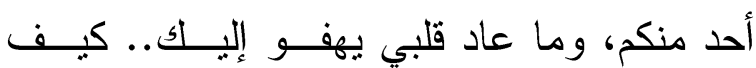
احتملت أنفاسك اللافحة لــوجهي طيلـــة الفتــرة الماضية؟ لقد رضيت بك، فرضيت أنــث عـنـ نفسك تمامًا. لم تتقدم خطوة و احدة خلال ســبع سنين. أنت أنت مصمم أغلفة البسكويت مغدور الشأن. مغمور الر أي. مغمور الوعي.. ارحـلـ عن سريري، فإنني على وشــــ الرحيـلـ عـنـ عالمك كله.. حطامك كله."ص بك و هو نوع من "التخيلات و الرغبات و الآلام التي لا تبوح بها لشخص آخر، فتبوح بها للقارئ حين يسترق السمع إلى أفكار ها، وبالتالي يمكـنـ 
يكون من الأسباب، التي أدت إلى الثورة علـى لـى

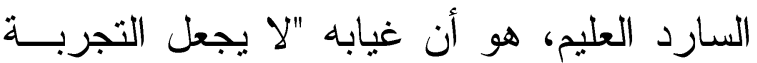

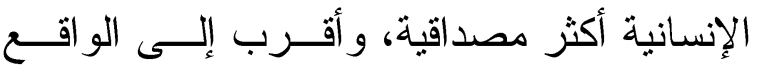
فحسب، بل إنه يعين المثل الجمالية، والقيم الفنية على جذب المشاهد إلى أعماق الحدث و المنـــاخ العاطفي السائد في الرواية"(^).

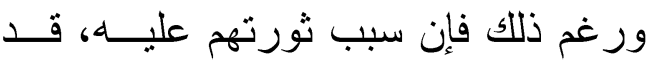

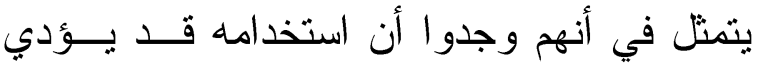
"إلىل/ التفكلك، و عدم التتاسق، حيث إن الانتقـــال الدفاجئ من مكان إلى مكان، أو من زمان إلــي

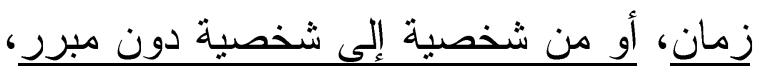

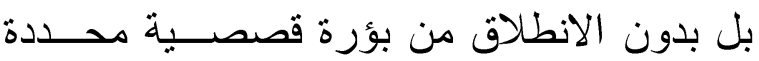

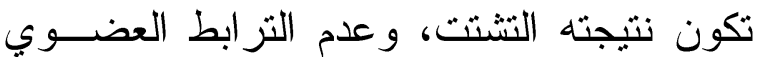

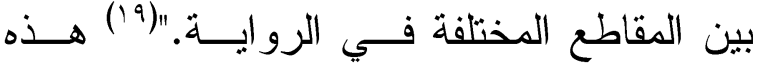

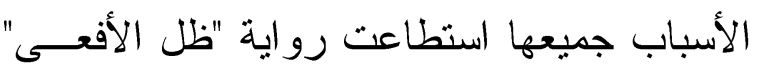
أن تتجنبها، فعلى مستوى المكان نجد أن الأماكن التي تتحرك فيها الثخصية الرئيسة محددة، وهي

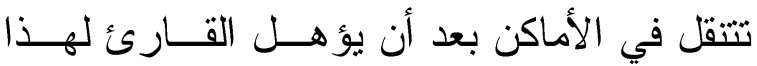
الانتقال، فهي تبدأ بنقطة البدايـة، و الثخصـية الثية الرئيسة ( الزوج) على سلم المنزل الذي يصـفهـ

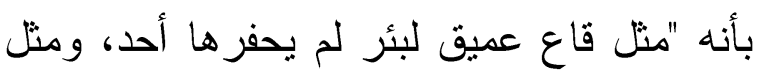

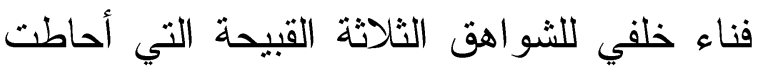
بإحكام خانق."ص9، فأهَّل هذا الوصف القــارئ

(1) روجر ب. هينكل، قر اءة الرو اية مدخل إلى تقنيات

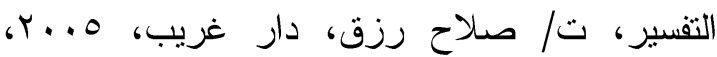

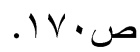
(9 (1) سيزا أحمد قاسم، بناء الرواية، دراسة مقارنة لثلاثية نجيب محفوظ، الهيئة المصرية العامة للكتاب 沼
زوجها، بل إن البحث يجد أن هـــه الحـــوارات

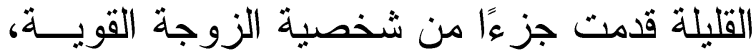
في مقابل شخصية الزوج الضعيفة، وقد يعنـي الني

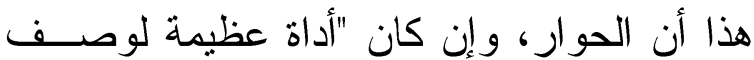
الشخصية، إلا أنه يتعين عليك الحذر حيال متى إنى

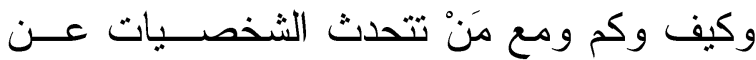

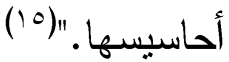

اعتمد الكاتب أسلوب الحوار الداخلي ليكون وسيطًا سرديَّا بين السارد و القارئ "و الوســبطة توقظ باستمرار التوتر الدلالي للخطاب، وتخبرنا بدون انقطاع أن هناك أو سيكون هناك معنـى، فالوظيفة الثابتة للوسيطة هي إذن على كل حال وظيفة لغوية... إنها تحافظ على الاتصال بـين لـاني

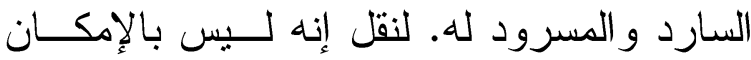
حذف نواة دون تحريف القصة، ولكـنـ/ أيضًا

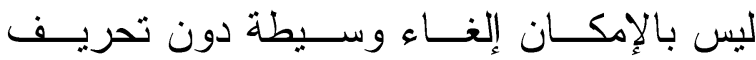

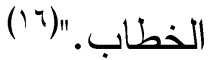

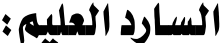

استخدم الكاتب في حدث الرواية الســارد

العليم، رغم أنه منذ "بداية العصر الحـديث ...

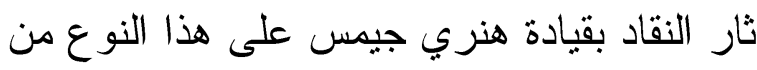

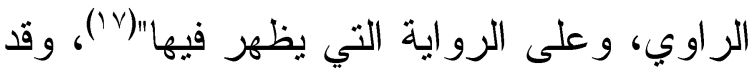

(10) نانسي كريس، تنتيات كتابة الرواية، ص100. (17) مجموعة من المؤلفين، طرائق تحليل السرد الأدبي، مقال(رولان بارت التحليل البنيوي للسرد)،

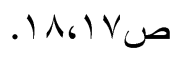

(أنجيل بطرس سمعان، دراسات في الرواية (IV)

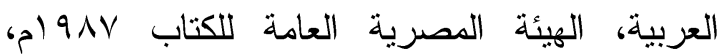


"سكر" صديقة "نايل"، فيقول: "دخلت عليهما سكر مــن غرفــة النــوم الضـــقية إلــى الصــــالة الضيقة."ص • - مصن إن انتقال الشخصية في المكان ليس مفاجئا، بحيث قد يؤدي إلى تشتت القارئ، بل لقد رأينــا السارد يتابع شخصية الزوج فقط في حركته في المكان، فلم يخر ج في هذا إلى شخصية أخــرى، فجعل شخصية الزوج وحدها هي المتحركة في

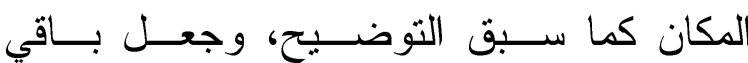
الشخصيات ثابتة، وهو ينفي حجة الانتقال مــن شخصية لأخرى دون مبرر، لأن حــدث "ظـلـل الأفعى" -كما سيظهر بعد ذلك- يدور من وجهة

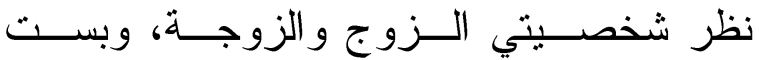
شخصيات فقط. أما عن الانتقال في الزمان، فــان حــــث الرواية يدور في مدة زمنية لا تزيد عــن ســـ عشرة ساعة، ولقد وصل الأمر بالسارد ليتجنب الانتقال المفاجئ إلى أن بحدد الزمن بالســـاعة، ومن أمثلة ذلك؛ يحدد وقت وصول الجـــد إلـى لـى

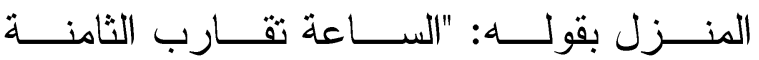
مساءً."ص rV ويحدد وقت الانصـــر اف بقولــه: "عقارب الساعة تعدت العاشرة."صعــ مما قــــ يشير إلى أن وقت بقاء الجد مع الزوج و الزوجة ساعتان "sن الثامنة إلى العاشرة"، وهذا الوقـــ

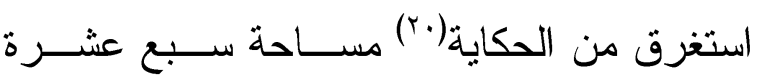

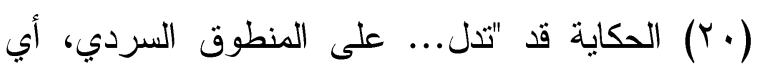
الخطاب الثفوي أو المكتوب الذب يضطلع برواية

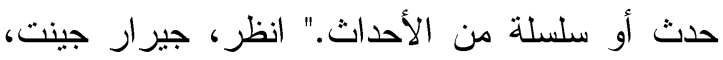
خطاب الحكاية، ت/ محمد المعتصم، عبد الجليل
لأن يتوقع منذ البداية الحالة النفسية التي تعيشها الشخصية الرئيسة. أخذ السـارد بيد القــارئ مـــع الشخصــية ليصعد به درجات السلم، فيصل إلى "سلم الدور الثاني الأخير"ص • (، و الــذي "درجاتـــهـ أكثــر

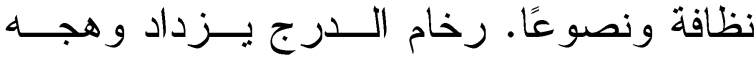
الأبيض، كلما ارتقاه.. بدت لعينيه الدرجة العالية

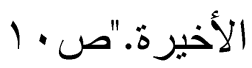
وهو وصف يعطي للقارئ دلالتين؛ الأولى: المنزل ينكون من دورين، و الثانية: نظافة الدور الثاني عن الأول مما قد يعني أن الدور الأول لا

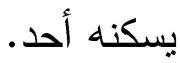
ينتقل السارد بالقارئ بعد ذلك إلى الشــقة، فيقدم لها وصفًا من تبئير الشخصــية الرئيســـة، و هي تقف على السلم، فيقول: "انتبــهـ إلــى أن صوتها الناعم ككل ما فيها، يكاد يأتي خفيضًا من داخل الشقة، من الجانب الأيمــن مــن الصـــالة الرطبة، من البقعة الوحيدة الخالية من الأثـاث،

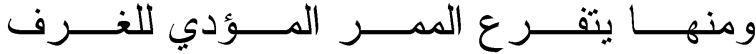
الثلاث."ص r ا و هو وصف يؤكد ما سبق ذكره من إحاطة الثواهق الثلاثــة بــالمنزل، فمنــع

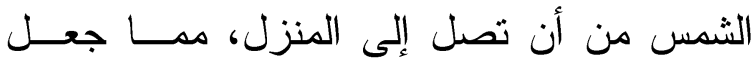
الصالة رطبة. ويوضتح أن الثقة تتكــون مــن ثلاث غرف. تستمر حركة الزوج مع الزوجة والجد في هذه الثقة حتى صو؟ عندما يخرج الزوج إلى صديقه "نايل". يقول: "اتصل بصديقه نايل، فتأكد من أنه في شقته الكائنة على بعـــد دقــائق مــن منزله."ص 9 ؛ ويصف شقة نايل من خلال حركة 
له هويته، منه ينطق، ومنه يمارس اللعبة الفنية، أو باتجاهه يمارس هذه اللعبة بانيًا عالم قصــهـ. الموقع هو أبدًا أيديولوجي، لكن هيمنته تعني، في نظر الكثيرين. هيمنة هوية أيديولوجية معينة... الكاتب معني طبعًا بهذه الهوية، و إن نجح فنيَّا بتلبس لبوس الحيادية، وتوسل تقنيات الخفاء."(rY) r-1 - ا تلخل السارد بالوصف:

المقصود بالوصف هنا ليس وصف مكــان

أو شخصية، بل وصف موقف ما يوضـــح بـــه السارد العلاقة بين الثخصيتين الرئيستين، ومن أمثلته هذا الوصف الذي يقدمه السارد في صو 1 يصور به لحظة الجماع بين الزوج والزوجــة، فيصف أن الزوج "رفع كفيه ببطء نحو إبطيهــا، ثم قارب بينهما ليحف ثدييها. مدت يدها اليمنـى "الي

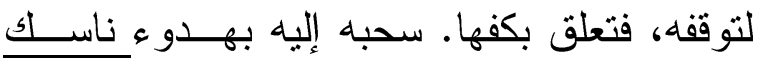
مخلص يجثو أمام تمثال إله قديم منــدثر. مــر بباطن كفها على وجهه. اغتسل بنــور أناملهــــا.

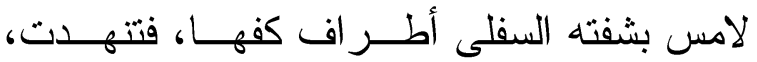

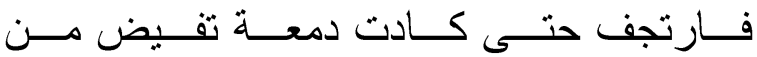
عينيه."ص 19

يصف السارد لحظة جماع بين زوجـين، لكنه لا يكتقي بالوصف، فيعرض وجهة نظــره بنوع من الانحياز للأنثى فيمــا يــدور أمامـــه، فعبارة "سحبه إليه بهدوء ناسك مخلص يجثو أمام

(YT) يمنى العيد، الراوي؛ الموقع و الثكل (دراسة في

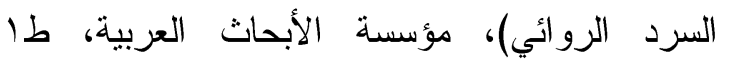

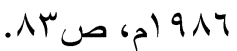

صفحة كاملة، وهو ما ينفــي حجــة الانتقــال المفاجئ في الزمان. ومما يؤكد ذلك أن خروجه

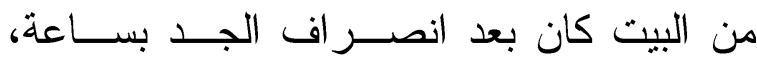
واستغرق من الحكاية ست صــفحات. يقــول: "عقارب الساعة تلسع الحادية عشرة."ص • ومن هنا قد يكون استخدام الكاتب للســارد العليم هو رغبته في الاعتمــاد علــى الحـــوار الداخلي في تقديم وجهات النظر في الرواية، وقد نتساءل لماذا لم يعتمد الكاتـب علــى الســـارد بضمير "أنا" السارد البطل يقدم شخصيته، وذلك بأسلوب السارد المتعدد بين الزوجين، بما أن هذا النوع قد يبرز فيه المنولوج، كما فـي الســارد

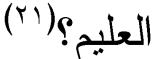

وقد تكون الإجابة أن الكاتب لجأ للســارد العليم بدلاً من السارد البطل لأنه أر اد أن يعرض الِّله لوجهتي نظر الشخصيتين الرئيستين، وبجانبهما يعرض لوجهة نظره، بتدخلاته المختلفة، ومثاله: ب_ إخلات السارد:

قد بحتاج موقف ما تــدخلاً مــن الســـارد ليوضحه للقارئ سو اء بالوصف أو بطرح رأي ما، وهذا التدخل قد يكون انحيازًا لشخصية على حساب شخصية أخرى، فالسارد قد يكون منحازًا "إلى بطله؛ الشخص أو الرمز. منحازًا في موقع الأزدي، عمر حلى، المجلس الأعلى للتقافة ... بحم،

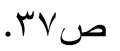
(Y) هذا السؤال يعرضه البحث رغم قناعته التامة، بأن الكاتب حر في اختبار سارده ما دام يستطيع أن يعرض به الحدث دون أن يجور على تقنيات السرد

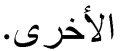


r-1-r التوجه المباثر إلى القارئ:

هو تدخل من السارد بعـرض رأيسـهـ إزاء

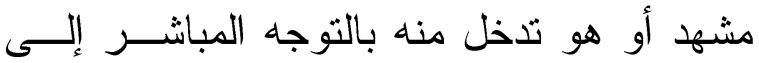
القارئ، ومن أمثلة هذا التدخل بالتوجه المباثــر بلـر إلى القارئ، ما نجده في قوله: "أضاف نايل أنها

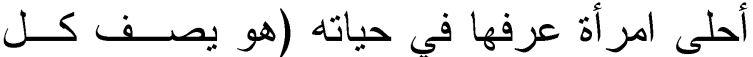
حريمه بهذا) لكنها لابد أن ترحل الآن."صعه اله

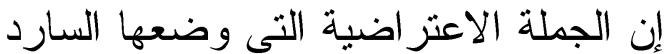

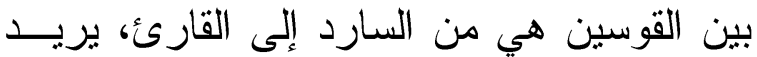

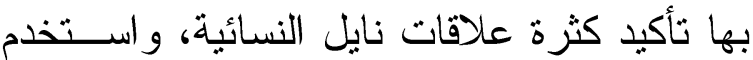
في الجملة الاعتر اضية "حريمه"، فاستخدم كلمــة

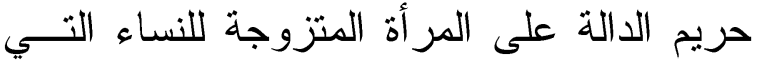
يلتقي بهن نايل، و هو بهذا برفض هذا النوع من

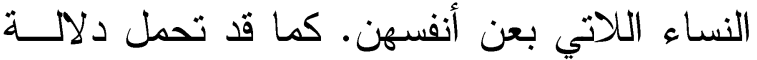

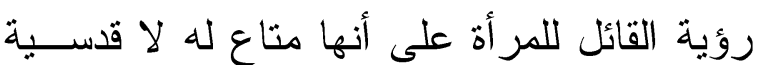

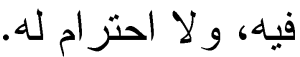
وفي الصفحة ذاتها يقدم شكاية "عبده" مسنـ زوجنه لنايل، ويصف له "كيف فرح بهــا يـوم لهون التقاها، وفرح يوم و افقت على الــزواج منـــه، وفرح بانتظام الأمر في سنوات الزواج الأولـى لـى (كان نايل يعرف كل ذلك)."

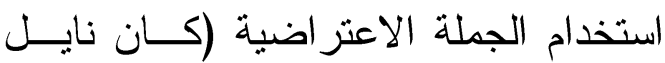
يعرف كل ذلك) تدل على أنها حكاية مكررة من عبده، ولكن استخدامها بعد جملة "وفرح بانتظام الأمر في سنوات الزواج الأولى" قد تمثل نوعُّــا

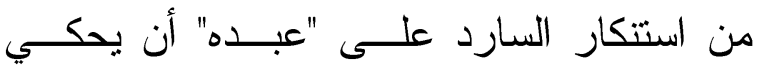
لصديقه خصوصية العلاقة مع زوجته.

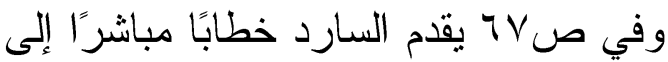
القارئ عندما يشير إلى الوريقات التي وقعت من
تمثئل إله قديم مندثر"، وجملـــة "اغتســل بنــــور أناملها" هي وجهة نظر السارد، وليست ملاحظة

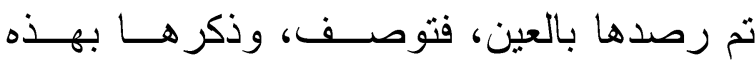
الخاصية إنما تؤكد هذه القداسة للأنثى، و التـي فئي يبحث عنها السارد في النص الروائي. يكمل السارد هذه اللحظة المقدة من هدوء الناسك أمام التمثال، بعد حوار بكلمة واحدة، فلقد

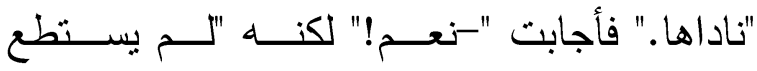

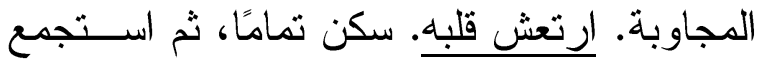
وجوده كله، ليندس بين نهديها. التصق بشدة. ود لو غاص فيها حتى يتلاشى تمامًا؛ عله يولد ثانية من رحمها. مرت بكفيها على كثفيه. استسلم لها حسين رفعتّه بأمر خفي. أنزى هل مالت هي نحوه حتى لهى

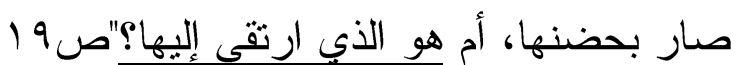
يزعم البحث أن ما نم وضع خط تحته من جمل هو وجهة نظر السارد إزاء ما يدور أمامه، ويصفه. ولنا أن نقارن في الســؤال الأخيــر بــين

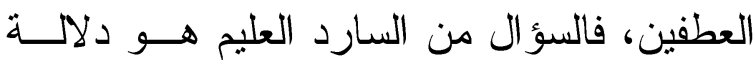

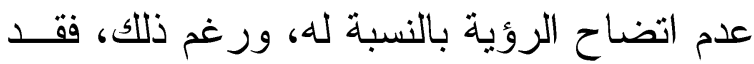

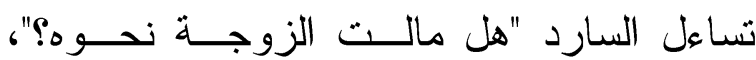
وتساءل "أم أن الزوج هو الذي ارتقــى إليهـــا؟

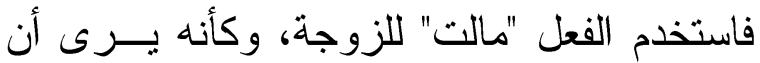

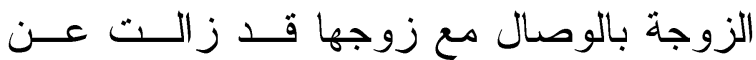

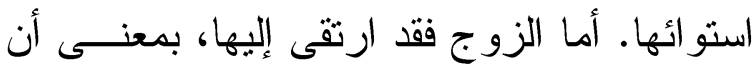

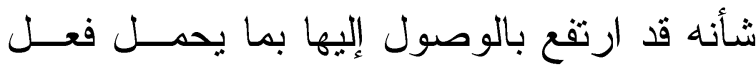
الارتقاء من قداسة. 
و اقعي، وينوجه في دلالته نحو مزيد من الوعي، أو نحو وضع الإنسان القارئ وضع المســاءلة و الرؤية الكاشفة. الأدب هنا يمارس على مستو اه التقافي، ومــن حبــث هـــو قـص دورًا فـي

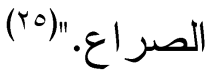

ورغم هذه التخخلات من السارد، فإنه فـي

هذا يحاول أن يصدر رؤيته من تبئير شخصيتين متقابلتين، وهما الزو ج (عبده) و الزووجــة. إنـــه "قص يصدر عن راويين بطلين لهمــا موقعــان

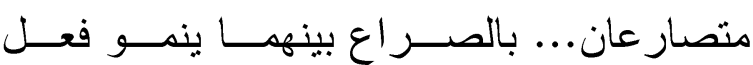

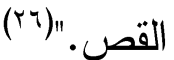
كما أن السارد قد يمهد للحوار الداخلي للشخصية

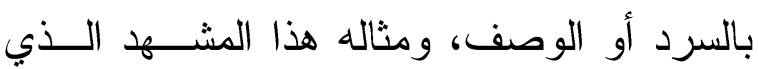
عرض فيه تذكر "عبده" يومي وفاة جده وجدته، فقدم السارد العليم هذا بقوله: "تتهـ عبده لحظـــة

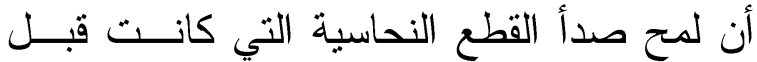
عقود من الزمان، تزين باب الثقة. تذكر يومي وفاة جده وجدته، كلاهما مات في صحة مقبولة بالنسبة لمن يناهز الثمانين!"ص • ثم ينتقل إلى الحوار الداخلي من "عبــده"،

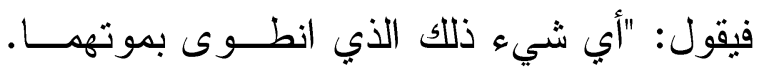

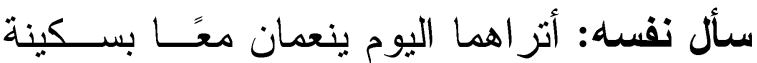
الخلود، ويرتعان في رياض الجنة؟ جاوب نفسه بما معناه: ربما يرتع الجد، أما الجدة، فلا يبــدو

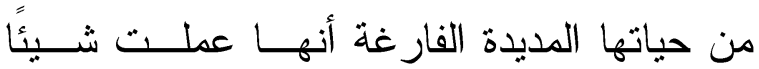
تستحق الخلود و الرتع، وما الذي ســـيخلد منهــــا

(Y0) يمنى العيد، الر اوي؛ الموقع و الثنكل (دراسة في

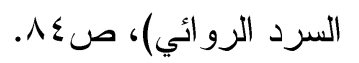

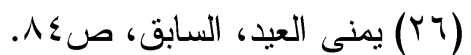

الزوجة، وير اها "بدت كبقعة ضوء على أرضية الغرفة الداكنة"، فيقول: "لو اقتربنا من أرضــية هذا الكون المسمى غرفتها، فسوف نرى بوضوح

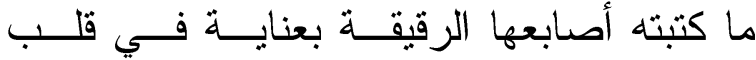
الوريقات."(זr) ثم يوقف السارد الحدث لثــــي ورقات كاملة لبعرض ما تحتويه هذه الوريقات، و التي هي عبارة ثنتا عشرة قطعة من التــر انيم المصرية و السومرية و البابلية، و أنشودة سومرية من القرن 9 اق.م، وجزء مـــن ملحمـــة إنانـــا

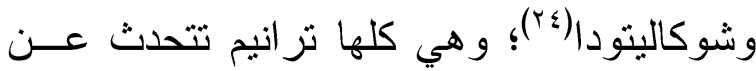
قدسية المرأة، وتر اها الربة الأولى، أو كما يقول في إحدى التر انيم:

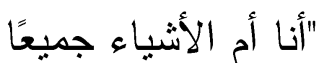

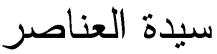

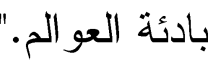

وهو وقف لا داعي لله، و الغرض الوحيــــ منه هو إكمال إثبات قدسية المر أة باستشــهادات قديمة، وهو ما قد يؤكد الانحياز الكامـلـل مــن

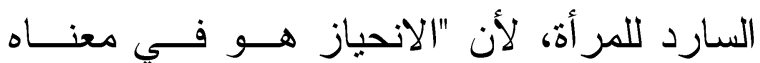

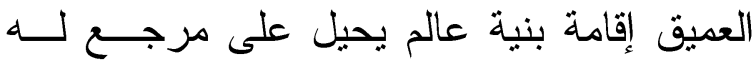
(Yr (Y) تتضمن هذه الفقرة ما يفيد قدسية هذه الوريقات

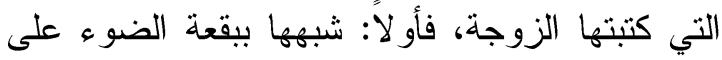

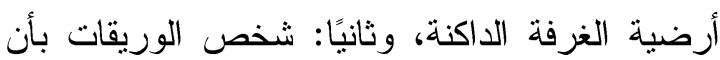

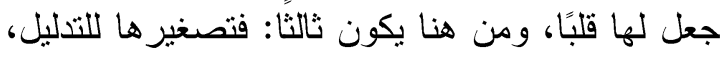

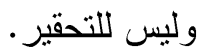

إنانا هي إلهة الخصب، وشوكاليتودا هو البستاني (Y )

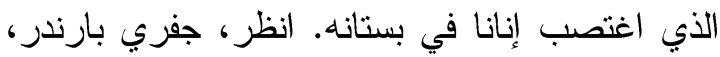

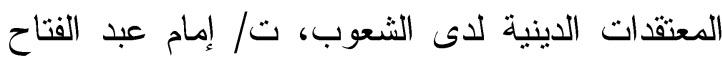

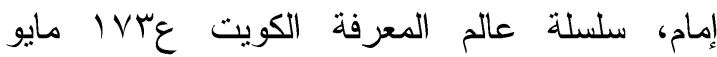

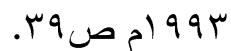


نفسه بما يستحيل البوح به:"ص بـ و "ثماوجـــ بر أسه أفكار الأسى، وتــرددت رنــات رثنائــهـ لذاته."ص بـ أو بقوله: "مر بذهنه المرهق سؤ ال مترنح"ص^وهوهي كلها تمهيدات يبين للقـارئ منها أن السارد العليم سيترك الســرد، ويتركــه للحوار الداخلي من الشخصية. لكن قد يقدم السارد الحوار الداخلي دون أن يمهد لله، فيحدث هنا نوع مــن التــداخل بــين ضميري "هو" السارد العليم، و "أنا" الشخصبية في

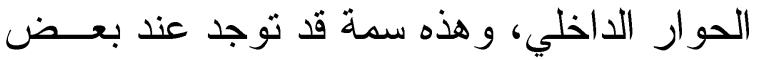
الكتاب، و الغرض من طمس علامات الاقتبــــ هو أن "يجعل الحدود بين خطاب السارد وخطاب

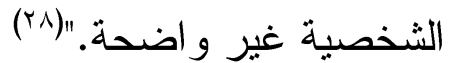
ومن أمثلة هذه الحوارات الداخليــة التـي تكون بلا تمهيد من السارد، ما نجده في حوارات

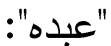
'ـ في صوء يقول في حوار داخلي لـــ

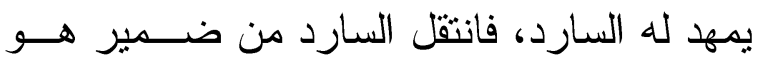
(السارد العليم)، إلى ضمير أنا (عبده)، فيةــــــ "أهذه هي المر أة التي كانت تطبر فرحًا إذا دعاها

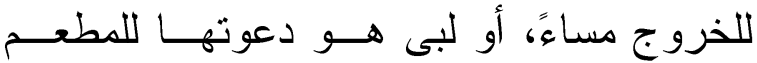
الخلوي الفاخر · مـا الأي جرى لهاب الخروج هو هو، والمطعم هو هو، و أنا أنا.. إذن هي التـي تغيرت. قد يكون ما ظلله، ووضـع تحته خـط هـــو نقطة الالتفات بين سرد السارد العليم، وسرد عبد

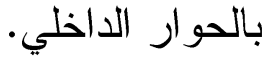

بالضبط! وهي التي قضــــ الأعــــام الثنالثـين

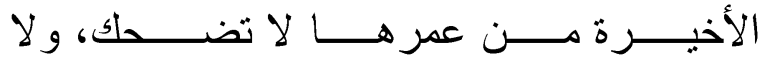
تبكي."ص • 1 فعرض من السارد وصف صــدأ القطع النحاسية، وكانت قبل ذلك في حياة الجدين تزين باب الثقة، مما قد يوضح هـــا الإهمـــال الذي حدث للشقة بعد وفاة الجــدين، لكنـــه فــي

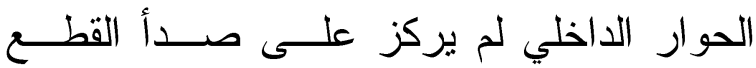
النحاسية، وركز بدلا منها على أهمبة حياة الجد التي قد تدفعه إلى أن يرتع في الجنة، بينما حياة الجدة كانت فار غة، فلا تستحق سمن وجهة نظر عبده- أن ترتع في الجنة. قد يعني هذا الإجراء من السارد العليم أننا لا نستطيع أن نفصل بين وظيفة الحوار الداخلي من الشخصية، ووظيفة التخخلات مــن الســـارد العليم، فهناك علاقات قد تبــدو و اضــــة بــين الوظيفتين، ويتمثل دور البحــث "فــي تعيــين الوظيفة و المحيط -ـأي العلاقات بين العناصــر ،

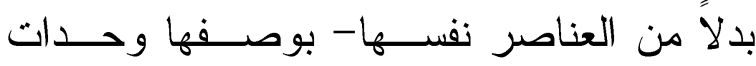
أساسية في السرد."(YV)

وقد يدفعنا هذا إلى البحث عن كيفية عرض السارد العليم للحوارات الداخلية من الشخصيات، فنجد أن السارد العليم قد يعرض الحوار الداخلي بالتمهيد كما في الحوار السابق، بقولـــه: "ســـأل

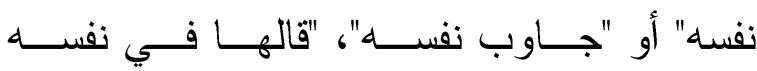

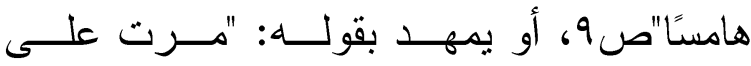
خاطره"ص اץ و "ناجى نفسه:"صس ع و "حــادث (YV) و الاس مارتن، نظريات السرد الحديثة، ت/ حياة

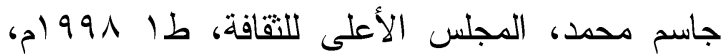


وقد تدخل هذه الحـــوار ات الداخليــة دون

تمهيد في حيز التداخل بين سرد السارد وخطاب الشخصية، "ففي الخطاب يتكلم أحد ما، وموقفـــه داخل فعل الكلام نفسه، وهو ما يثـــكل بــؤرة الدلالات الأكثر أهمية؛ أما في السرد، فلا أحسـ يتكلم كما يشدد على ذلك بنفنسيت/ وبهذا المعنى لا يصير من حقنا في أية لحظة أن نسأل عمـن يتكلم... لكي نتلقى دلالـــة الـــص تامــة غيــر

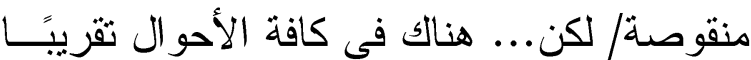
نسبة من السرد متضمنة في الخطاب، ومقــدار من الخطاب في السرد.... و السبب هو أن هـــهـ العناصر تظل مشدودة في الغالب إلى مرجعيــة المتكلم الذي يستمر حضوره ضمنيَّا في الخلفية،

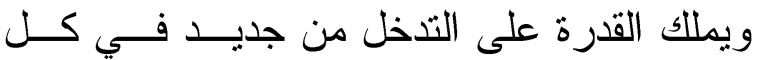
الأثناء بدون أن ينظــر إلـى هــــه المعــاودة (باعتباره) تدخلاً. (ra)

وقد يكون هذا حال السارد العلـيم الـــي

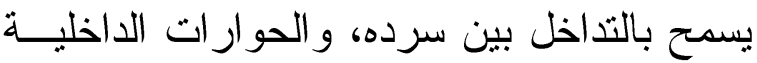
دون أن يبرز للقارئ أن هناك نوعًا من الحوار الداخلي للشخصية.

لكن قد توجد حوارات داخلية من الثخصية

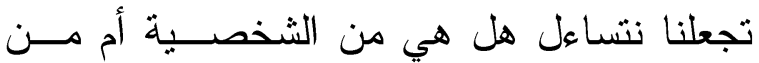

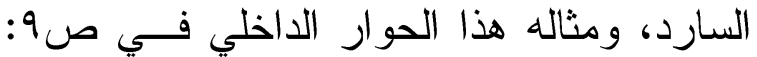

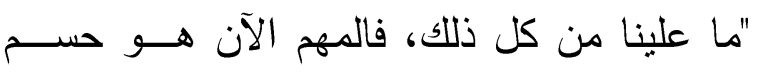

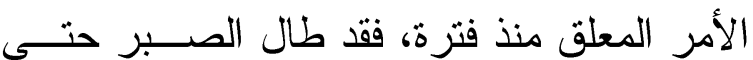
تقطعت أوصاله."

(Yq) مجموعة من المؤلفين، طرائق تحليل السرد

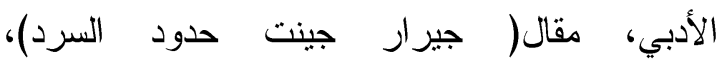

r_ في ص99 في آخر حوار داخلي مسن

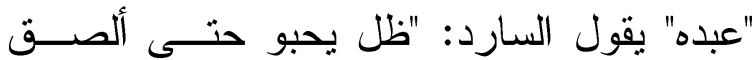

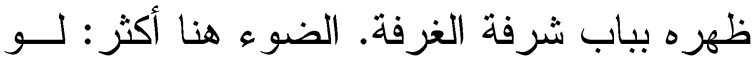

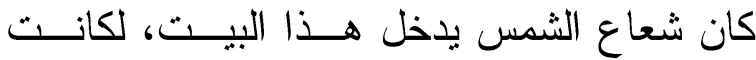

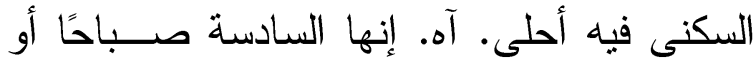

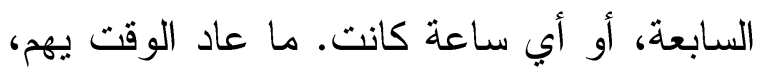
فالمهم الآن أن أرتاح. لا راحة في هذا البيــت.

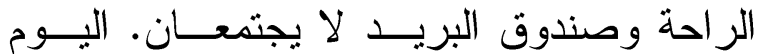
سأنز عه من مكانه. سأحرقه." البداية في هذا الحوار الداخلي قـــــــــــــن ملبسة، فــلو كان شعاع الثـــس يـــذل هــــا البيت، لكانت السكنى فيه أحلى." هذه الجملة هل هي من السارد العليم أم من عبده، وبخاصة أنه

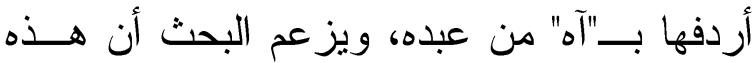

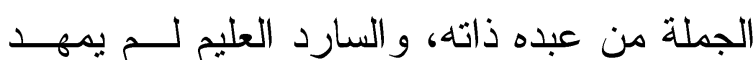

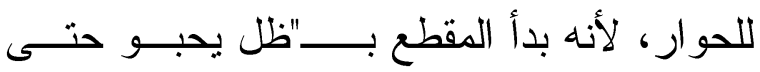

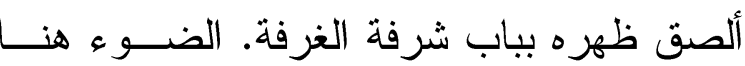

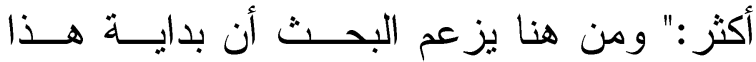
الحوار من "الضوء هنا أكثر."

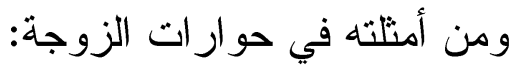
في صبr يأتي الحوار الداخلي دون تمهيد من السارد، لكنه لا يدخل في حيز الالتفات، لأنه جاء بعد حوار خارجي بين عبده والزوجة، الذي انتهى بسؤ اله عن لغة الأغاني التـي تســمعها، وعن سؤاله هل تتعلمها، فنتركه دون الرد عليه، لتدخل في هذا الحوار الداخلي. تقول: "ماذا تريد مني الآن؟ أرجوك لو كنت تحسـ أن تتركنـي

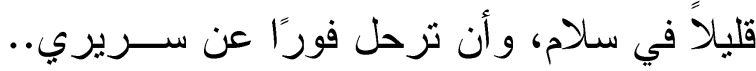
أين كان عقلي.. كيف تزوجت هذا الثخص؟ 
فالتشابه أو التقابل بين/ سلوكهما يؤكد الســمات

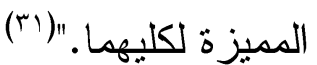

\section{ع_ا تقديم شخصيتي الزوج والزوجة:}

بدأ السارد الحدث بشخصية "الزوج"، وهو

على سلم العمارة، مما قد يدفع القارئ إلــى أن هذه الشخصية هي مَنْ ستتال درجة الاهنمام في

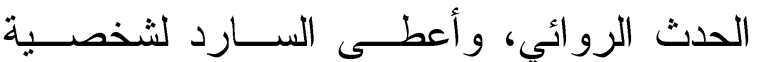
"الزوج" التبئير في بعض المو اقف، وكلها خاصة برؤية الزوجة.

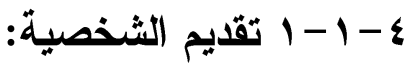

أعطى السارد لشخصية الزوج اسم "عبده"،

وو اضح الدلالة الخاصة بالاسم، والتي تتكون من كلمة "عبد" المضاف إليها ضمير الغائب "الهاء"، و الوعي الجمعي يرجع دلالة الهاء إلى الله وحده، فتكون العبادة لله.

وفي ص اب تتاديه الزوجة بـــــــبودي"،

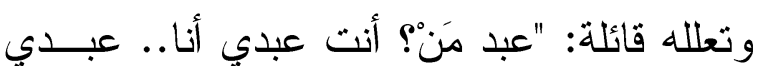
الصغير .. عبودي!" وقد يكون هذا دلالة علـى السخرية من الاسم، وهو ما ظهر عنــدما قـدم السارد سخرية الأم من هذا الاسم بإشـارتها فـي هي هوني إحدى رسائلها بقولها: "عبده! أي اسم هذا؟ كيف

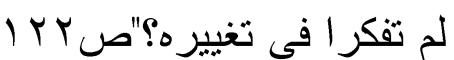
لم تكن تسمية الزوج من درجة الاهتمــام، بل هي سخرية من الشخصية، وبخاصة إذا ظهر

(ابr) شلوميت ريمون كنعان، التخييل القصصي الثعرية

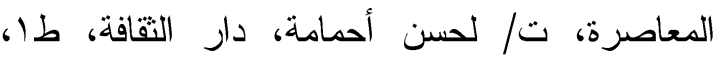
.1.7، 1.0.0 ص 1990
ومثل هذه الجمل التي لا تعرف هل هـي

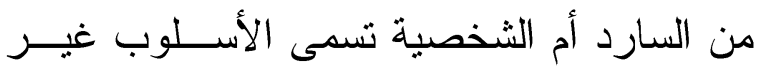
المباشر الحر، "فهي تــدعى "الأســلـوب غيــر المباشر الحر"... لدى الفرنسيين.../... ودعاها تشارلز بالي غير مباشرة لأنه اعتقد أنها مشتقة من الخطاب غير المباشر، وحرة لأنها حرة من الرو ابط، و اعتبر ها أسلوبًا لا شكلاً نحويًّا، لأنها تستببع مدى واسعًا من الابتعادات عن الاستعمال الطبيعي، و التي تظهر -في رأيه- فــي الكتابــة فقط، و أطلق الألمان عليهــا مصـــلح الكــلام المجرب... لأنهم اعتقدوا أن اســتخدامها يــدل

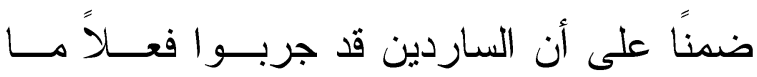
جربته الشخصيات... لدى الناقد الروسي باختين "خطاب مزدو ج الصوت"."(r)" لكن البحث يرجح أن هــذا الحــوار مــن الزوج، و إن لم يصر ح السارد بذلك بأن يقــول مثثلا "قال في نفســـه" أو بــأن يضــــع علامــــة تنصيص.

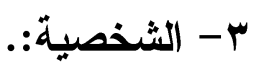

قدم السارد ست شخصيات، هي شخصبات

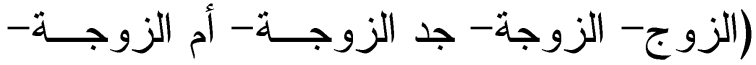
نايل صديق الزوج- سكر صديقة نايل). وسيقدم البحث للشخصيتين الرئيستين اللتين قامتا بالحوار الداخلي، وذلك من خلال التقابل بينهمـــا، لأنـــه

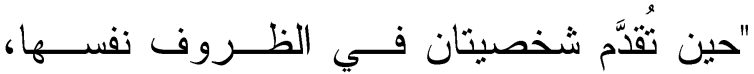
(r·) و والاس مارتن، نظريات السرد الحديثة، 
مارتن تصبح "الوظيفة هي التي تقرر المعنـى،

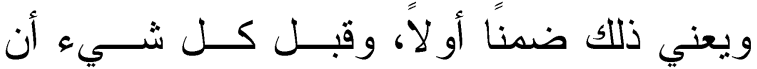
الأفعال Verbs أو الأحداث أهم بنيويًّا من الأسماء

أو الشخصيات." (rr)

تظهر درجات الاهتمام بشخصبة الزوجــة

على الزوج من خلال الأفعال من ثلاثة أمور:

أولاً: الأصل لكلا الزوجين:

لم يبرز السارد في مجال المقارنة أصــل

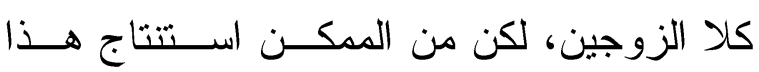
الأصل من خلال مشهد قدمه السارد باستباق في الصفحة الأولى للحدث الروائي. يقول: "منزلـــــ المتكوم بلا هيبة، القابع بلا حضور متميز فـي المكان، ومن حوله استطالت العمار ات، حتى بدا سطع المنزل مثل قاع عميق لبئر لـــ بحفرهــــا أحد، ومثل فناء خلفي للشواهق الثالثة القبيحـــة التي أحاطت به بإحكام خانق. حتى النو افذ التي

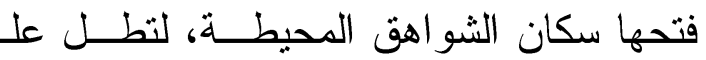
الفراغ المستقر فوق سقف المنزل، أُغلقت بعـــ الواقعة المشهورة التي رفعت رأس عبــده بــين جير انه التقلاء."ص يوضتح هذا الاستباق حقارة أصل "عبــده"، لأن البحث يزعم أن الأوصاف التــي أعطاهــا السارد للمنزل من كونه "متكوم بلا هيبة"، ومن

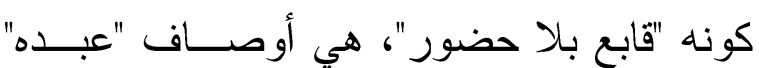
ذاته، لأنه "كثير ما تستعمل... الأشياء الفيزيقية المحيطة بالشخصية (الغرفة- المنزل- الثارعالمدينة)، وكذا محيطها البشري (العائلة- الطبقة
بعد ذللك أن دلالة الاسم هـــو عبوديــة الــزوج

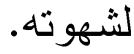

لم يعط السارد لشخصية الزوجـــة اســـًا، و اكتفى بالاسم أو الوصف الذي أطلقه عبده عليها "نو اعم"، و الذي يعلله عندما سألته "لمَ ناداها بهذا الاسم القديم، الذي لم يعد يستعمله اليوم أحدّ؟ قال

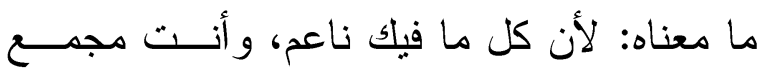
النعومة، و هذا اسمك عندي للأبد."ص ل اكتفى السارد بالوصف الذي أطلقه الزوج، لأن الزوجة شعرت بالنشوة عند سماعها بالاسم لأول مرة. يقول: "كانت النشوة تلفهـــا، بحيــــ زادتها الكلمة خدرًا على خدر ... كرر الكلمــة..

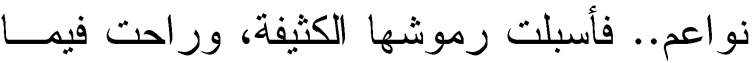
يشبه الغيبوبة."ص V ا فلم يكن عدم اهتمام السارد أن يذكر اسمًا للزوجة، و اكتفاؤه بوصف الزوج هو من قبيل عدم اهتمام السارد بالزوجة، بل قد يكون هو اهتمام عن طريق الاهتمــام بــدوائر

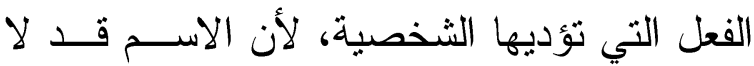
يدل مسماه على أسلوب حياة صاحبه، ومن هنــا فقد أخضع "بروب.... الثخوص إلى دوائر الفحل التي يمكن أن تصنف إنجاز اتها حسـبـ الأدوار

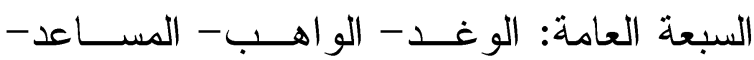

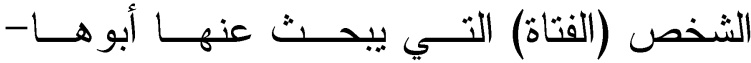
المرسل- البطل - البطل المزيـــ."(rr) ومــن خلال هذه الدوائر للفعل يزعم البحث أن الزوجة هنا تقوم بدورين، فهي الفتاة التي يبحث عنهــا زوجها، وهي البطل. فإذن كمـــا يقـرر والاس 


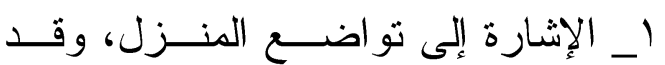

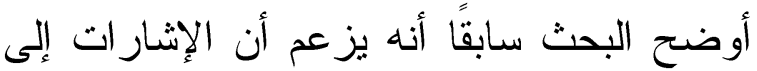
المنزل هي إثار ات إلى "عبده" ذاته. بـ قول الجد إن الثبابيك غير قانونيــة، فهذا القول يدل على ضعف "عبده" الذي يصمت على وضع غير قانوني، وينتظر سنوات حتى

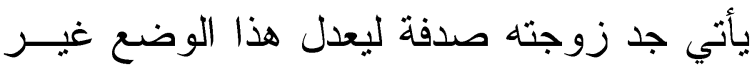

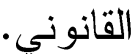

ومن تبئير "نو اعم" يوضح السارد أن هـــهـ

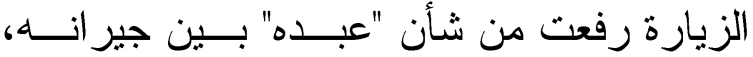
فيكون أصل الزوجة الرفيع هو من رفــع مـنـ

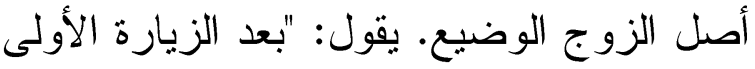

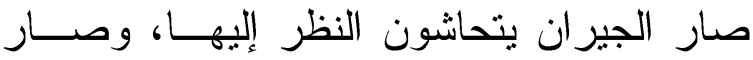
زوجها مرهوب الجانب."ص آس

إن السارد لم يشر صر احة إلى أصل كــالِ الزوجين، لكنه عرض لنا استباقا، ثم أوضح هذا

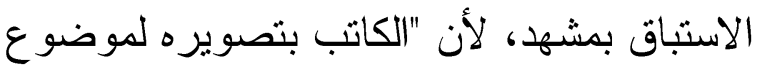

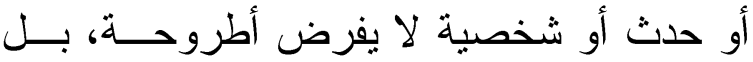
يحث القارئ على صياغتها. إنه يعرض بدل أن أن يفرض، و إذن يحفظ للقارئ حريته، في الآن ذاته

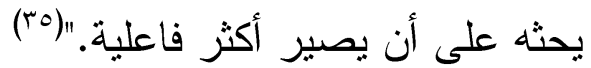
وإذا كان السارد لم يشر للأصل صراحة، فإن عبده يقدم ضعفه الذي ورثه من أسرثنه فـــي لـي الحوار الداخلي الذي يعترف فيه بضـــفه بعـد

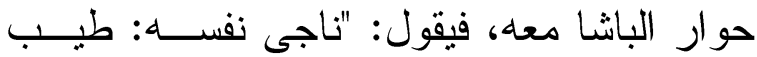

(T0) تزفيتان تودوروف، الأدب في خطر، ت/ عبد عبد

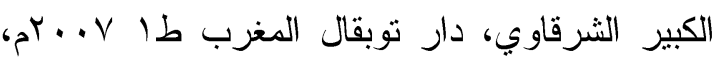

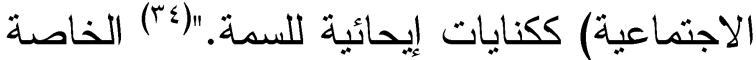

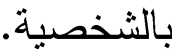
أما عن الو اقعة المشهورة التي رفعت رأسه

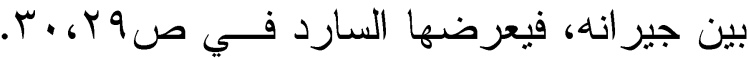
يقول: "وقفو ا ثلاثثهم على سطح البيت... أثثــار الباشا إثارته المتأففة ذاتها إلى جدران الثوان اهق الثلاثة، ثم قال بعظمة بعدما تتحنح: ــ إيه الشبابيك الكتيرة دي؟....... فالجد ينظر لأعلى، ويعرب عــن ضـــيقه

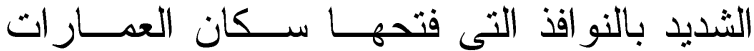
الثلاث، من قبل أن تعمر هي البيت بسنوات!... ولم يكن زوجها يرى ضررًا من تلك النو افــذ..

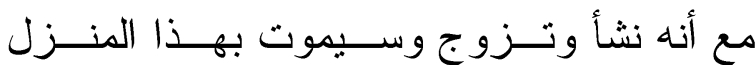
المتو اضع ذي الطابقين و السطح الخالي. أدار الجد رأسه في الجهات الثالاث... قال

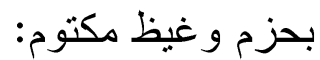

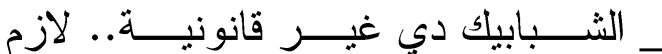

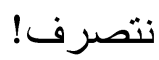
بعد يومين فقط أغلقــت النو افـــــــــــوب أسمنتي.... جميع النو افذ أُغلقت." وهنا يظهز مدى قوة أصل الزوجة المتمثل

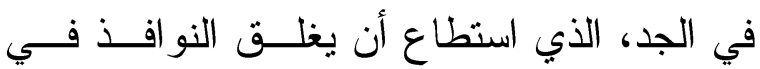

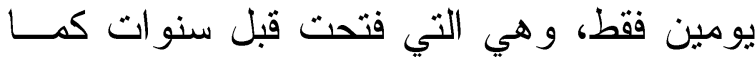
أشارت الزوجة. ولقد أثشار السارد إلى نقطتـين

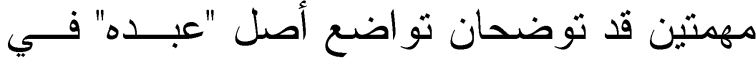
مقابل الزوجة "نو اعم"، وهما:

(ع ب) شلوميت ريمون كنعان، التخييل القصصي الثعرية 
الزوجة، بقدر اهتمامه بالسيارة، مما قد يدل على فقره وووضاعة أصله.

وتقدم الزوجة في حوار داخلي لأسرة عبده الريفية، وتؤكد طمعه فيها بسؤاله الــدائم عــن حسابها الشخصي، بينما يخفي عنهــا رصـــــه البنكي الحقير، فتقول: "اذهب ستجد فيها جهازك

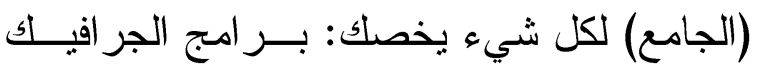
البلهاء. رسائل أصدقائك الإلكترونية التي تظــنـن أنك نجحت في إخفائها عني. صور أسرتك فـي

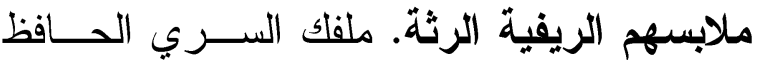
لصور العاهرات اللواتي عرفتهن قبلي وبعدي.. رصيدك البنكي الحقير الأي لم تخبرني يومًا به، بينما لا تكف عن محاولة اكتشــاف رصــيلي. اذهب إلى جهازك و اتركني، فلست فــي حاجـــة إلبك الآن، ولن أكون يومًا."صسا مما يدل على أن الحوار الداخلي أكد مــــا أشار إليه السارد من خلال الاستباق. ثانيًا : عمل الزوج في مقابل عمل الزوجة : أوضح السارد أن اللقاء الأول بينهما كــان "في حديقة المبنى الكبير المسمى مجمَّع التدريب الذي أرسلا إلبه، كل من جهته. هـــو لبــدرس لثالثة أشهر أصول توظيف الألوان البراقة فـي تصميمات أغلفة المنتجات الاستهلاكية صـــيرة الحجم! إذ كان لابد مسـن حصــوله علـى دورة التدريب السمجة هذه، ليمكنه اســتلام وظيفتــه الجديدة في قسم الجر افيـــك بالثـــركة الدوليـــة

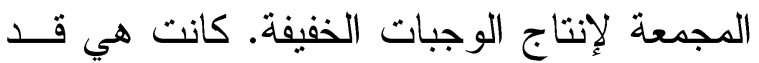
انتظمت في مركز التدريب من قبل مجيئه بسبعة أسابيع، بالدورة التدريبية عالية المستوى، لتطوير
وبعدين يا عبده؟ آخرتها إيه يا مسـكين. طبعَّا لازم تكون مسكين، زي أبوك و أمك. هــاتيجي القوة منين."صس؟ وفي حوار داخلي آخــر يقــدم لأســرته بفقرها وبالقرض الذي ورثه عن و الده، فيقــول:

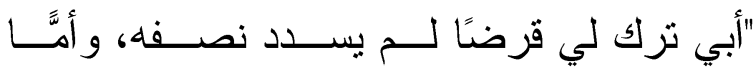
مريضة لحقت به بعد شهور ، وشقيقتين من ربات البيوت الفقيرة. لو لا جدي لأمي ومنزله الحقيــر هذا لكنت الآن أجوس الطرقات كالكلاب الضالة، وما كنت قد تزوجت حتى اليوم."صع ومن هنا وجدناه عندما تهجـره زوجتــه، وتأخذ السيارة لا يفكر في هذا الهجر، بل يفكـر في السيارة، وكيف أنها أخذتها رغم أنه هو الذي كان يتولى مصاريفها. يقول: "مر بذهنه المرهق

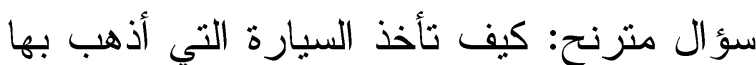
للعمل كل يوم؟ كيف؟ ثم طافت بر أســـه إجابــة مترنحة متشخشخة: صحيح أنها اشترت السيارة

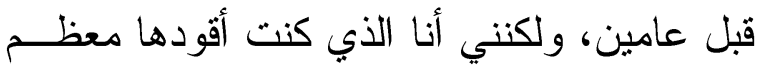
الأوقات. هي دفعت ثمنها، لكنني كنت أدفع ثمن وقودها معظم الأوقات. نحن شركاء فيها، فكيف تأخذها بهذه البساطة. الغادرة. آه أوراق السيارة مسجلة باسمها هي. لو كنت قد تحسـبـ لهــذا الغدر، ووفرت ثمن الوقود خلال عامين لكنــت اشتريت سيارة مسجلة باسمي، أو دفعت مقــدمًا لها وقسطت الباقي... لا يهم يا عبده. إذا كانت قد طمعت في السيارة فلتأخذها. سأذهب للعمل كـلـ لـ لـ يوم، بواحد من تللك التاكسـيات التـي تجــوب الشوار ع كالذباب!"ص^9 فهو لم يفكر في هجر 
ولهذا كانت الإشارة إلى أن راتب الزوجة يفوق راتب الزوج بثلاثة أضعاف. يقــول فـي إلى منولوج لــ"عبده": "إنها تعمل في وظيفة جيــدة؛ راتبها يزيد ثلاثة أضعاف عن راتبي، مع أنها لا لا

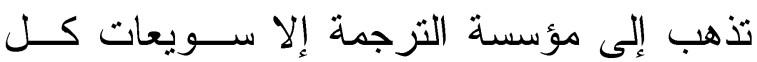

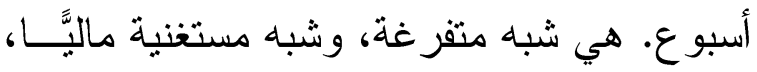

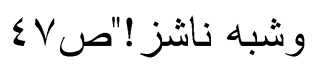

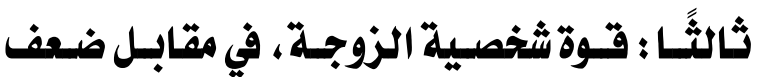
شخصية الزوج:

من أصلها الذي يفوق أصله، ومن عملهــا

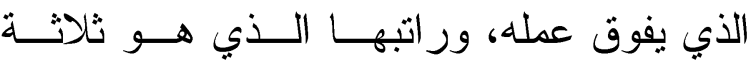
أضعاف راتبه، تكون قوة شخصيتها أمامه، و هذه

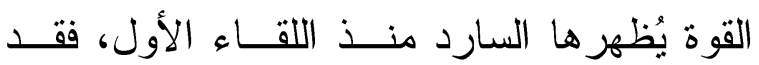

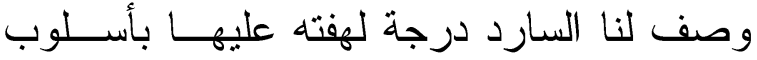
شاعري فيه تتاص قرآني ليجعلنا نشعر أننا أمام

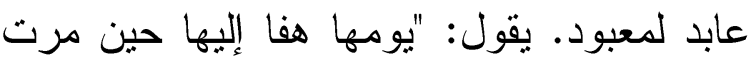

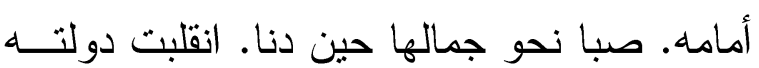
لما تدانت. ذاب لما حيته بابتسامة قاب متــرين أو / أدنى. تدله لما أوحت إليه بالاقتر اب أكثـر.

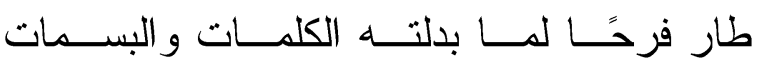

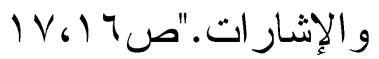

هذا التناص القرآني من سورة النجم جعل من شخصيته رد فعل إز اء فعلها، ولم يستطع أن

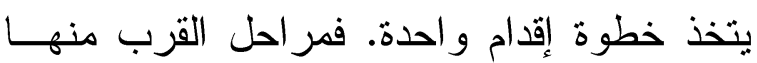
يقابله مر احل رد الفعل منه. عند مجرد القــرب

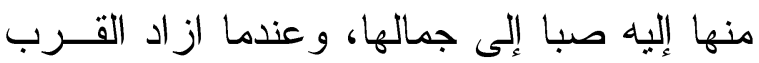
انقلبت دولته، وذاب لمجرد الابتسامة مسـن بعـــ

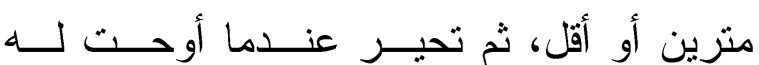

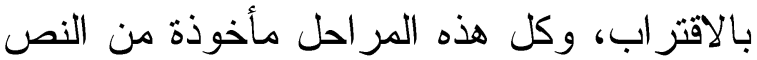

مهارات الترجمة ومعالجة الألفاظ المشتركة بين عدة لغات، استعدادًا لتسلم عملها كمترجمة فـي لئي الهيئة الدولية لضبط النصوص المنرجمة من كل لفال

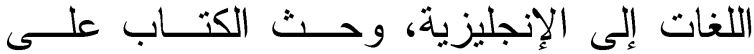

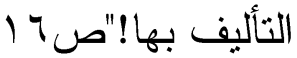
يبين هذا النص عدة أمسـور فـي مجــال

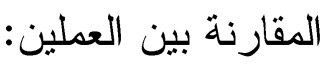
'ــ إن طبيعة عمل عبده يدوي و استهلاكي بالدرجة الأولى، فهو يعمل في الثركة الدوليــة

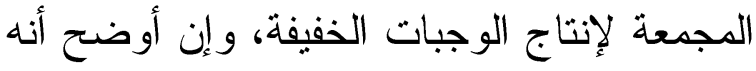

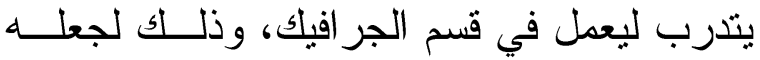

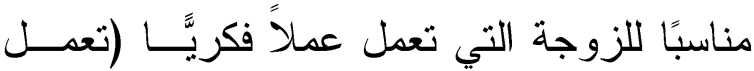

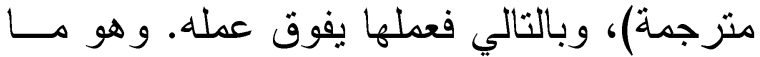

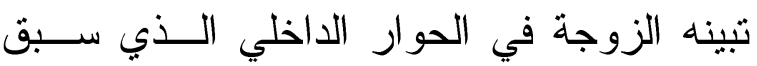
عرضه، عندما تزاه لم يتقام خطوة واحدة طيلة

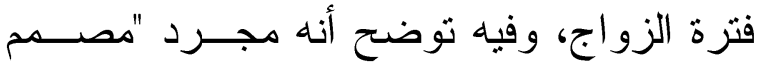

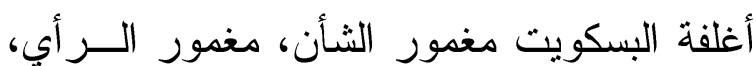
مغمور الوعي."

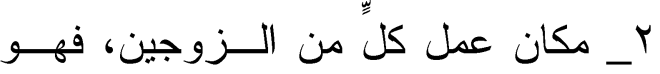
يعمل في شركة، وإن أطلق عليها الدولية، لكنها

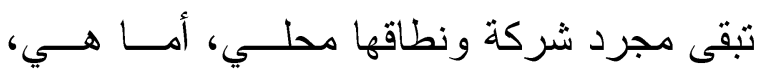

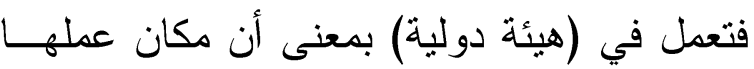
غير محدد في دولة بعينها.

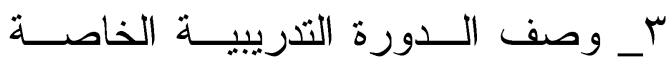
بالزوج بالسمجة يدل على عدم اقتتاعه بالدورة،

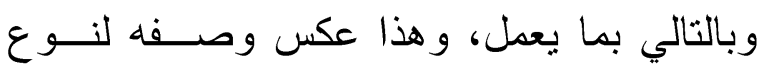

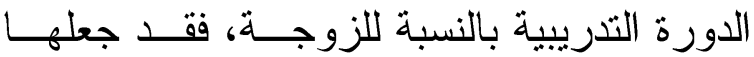

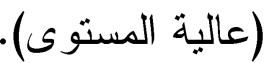


ثانيًا: يوضتح الحوار المشـــاعر الحقيقبـــة لعبده من الجد، وهي كره للجد، وذلك بترديـــه لجمل "حاضر يا غتيت.. حاضر يا ابن الكلب." ثالثًا: دلع الحفيدة في قوله: "ومع الدلوعـــة

حفيدتك.

رابعًا: اختيار الصبر مبدأ له، ولقد صــور

في هذا المنولوج أن الصــبر مــن مبــدأ قـوة شخصية عبده، فقــال: "لمـــا نشـــوف آخرتهـــا معاك... الصبر عمومًا حلو ومطلوب." فجملـــة "لما نشوف آخرتها معاك" قد تفيد دلالة التهديـــد، وهو ما سيظهر عكسه بعد ذلك، لأننـــا إذا كنـــا إزاء عمل روائي يُروى "بصيغة المتكلم، فــانِ

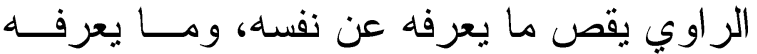
عنها فقط. أما في الحوار الداخلي، فذلك يتقلص بازدياد إذ لا يمكنه أن يروي إلا ما يعرفه عـنـ نفسه في هذه اللحظة بالذات، فــنحن إذن أمـــام ضمير مغلق، وتبدو القر اعة عندئذ كأنهـــا حلــم

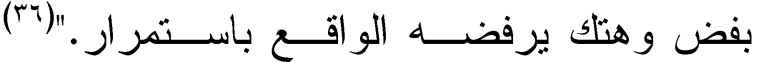
و الشخصية التي تتولى الحـــوار الــداخلي هـي وحدها القادرة على هنك هذا الحلم المختفي عن

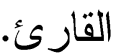

وفي تعليق آخر من عبده على حوار عنيف بين الجد والزوجة، وفيه يتوعد الجد الزوجــة، فيقول: "- اسمعي. إنتِ تقومي/ دلوقتي وتحرقي الجوابات دي كلها، وتبطلي تتصلي بيهــا، و إلا و الله.. و الله لو خربتي بيتلك بأفكار ها السودا، أنا

(Tr) ميشال بوتور، بحوث في الرواية الجديدة، ت/

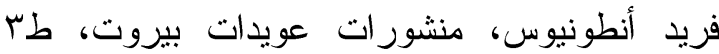

القر آني "ثم دنا فتللى، فكان قاب قوسين أو أدنى" سورة النجم آية ^،9. ولهذا كان الختام بالطيران فرحًا لما بادلته الكلمات. يكمل السارد هذه السيطرة من الزوجة على الزوج بعد الزواج، ففي البداية بصــور علاقــة خوف الزوج من الجد، وإبراز المشاعر الداخلية للزوج، وذلك عندما يريد "عبــده" أن يعـرض رأيه، فيقول: "- في الحقيقة يا باشا.."صبكس ولم يكمل لأن الجد قال له: "اسكت أنت يا لهوبا عبده.. (قالها الجد بحزم)" فما كان من عبده إلا أن يقول: "حاضر يا

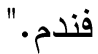
إلى هن الحوار عبارة عن أمر من الجــد، و استجابة مباشرة من عبده، لكن الحوار الداخلي بعد ذلك يبرز هذه المشـــاعر الداخليــة لعبــده، فيقول: "لا بأس. اسكت أنت يا عبده! حاضر يا فندم.. حاضر يا باشا.. حاضر يا كبير .. حاضر

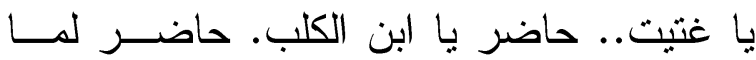
نشوف آخرتها معاك، ومع الدلوعة حفبــدتك... الصبر عمومًا حلو ومطلوب."صس يوضح هذا الحوار الداخلي عدة أمور :. أولاً: مدى خوف عبده من الجد، فلقد بدأ الحوار الداخلي بالحوار ذاته الذي دار بينه وبين الجد، و إن وضع بعد "اسكت أنت يا عبده" علامة التعجب، دلالة الدهشة أن بطلب منه السـكوت، و هو الذي استدعاه لكي يوضح له انقلاب حــال

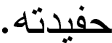

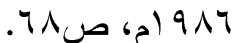


ثالثًا: قوة الجد وسطوته على الزوجة رغم

ردها العنيف، فهو "سيأمر ها بلهجة قاطعة".

ويرد "عبده" على النقطة الأولى، ويؤكـــ

الثانية عندما يتابع لحظات التمني بمنولوج آخر

قائلاً: "هو طبعًا لن يستأذن مني. ماشي الحــال. المهح إني سأستريح من قلقي منها، ومن اشتهائي لها لأيام، يتولى هو خلالها شطف كل الأفكـار الغريبة من رأسها. طبعًا، وستعود إلى حضــني كما كانت دومًا، امر أة شهية تحــب الالتصـــاق الليلي، وتدعي أنها حنون توفي زوجهـــا حقــه. ستعود حتمًا بعد أيام لتوفيني حقـي المسـلوب

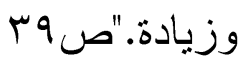

إن شخصية "عبده" ليست قوية كما أراد أن يؤهم، لأن الجد سيأمر دون أن يستأذن، بــلـ إن "عبده" لن يمانع، وسيرحب ما دام أن هذا الأمر سيرجع زوجته لسابق عهدها تحــب الالتصـــاق الليلي.

وبعد الحوار الخارجي الذي أســـت فيــــ

الزوجة عبده، وبعد انتصار الزوجة على الجــد، يقدم السارد هذا الحوار الداخلي، فيقول: "حــدَّث نفسه بعدما توارت، بما يود أن بعلنه: آه يا كلبة. إيه الجرأة دي على الباشـــا.. علــى الباشـــا.. تقاطعيه، وتجرحيه، وتتركيه وتمشي. طبعًا هيَّ دي آخرة الدلع. طيب آخرة الحكاية إيه؟ جــــك فظيع.. طبعًا ها يحطملك، ويحطمنـي معــاكي! طيب و أنا مالي. منك لله، إنتي و أمك."صكاع وك

الأولى. طلة العروس في كامل زينتها. هيجان جلسة السمر عند السكر.
هاخرب بيتها، و هأعرف أوصل لها في أي مكان

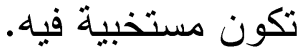
- ماما مش مستخبية يا جدو. - يعني إيه با بنت؟ - يعني مش معقول كده يا جدو . كفاية اللي عملته معاها زمان.. وبعدين هيَّ دلوقتي بتعمل دراسات مشهود لها في أكبر أكاديميات العــالم،

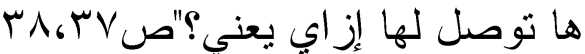
يعلق "عبده" على هذا الحوار العنيف بــين الجد و الزوجة بمنولوج أول ينمنى فيه "لو طلب أب أون

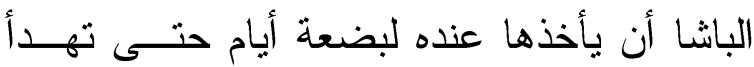
النفوس، فسوف أرحب. سأقضي هذه الأيام مــع صديقي الصدوق نايل. ســوف نمــرح كثيـرًا، ونز هلل معًا./ وبعد أيام ســـوف تشــناق لـي،

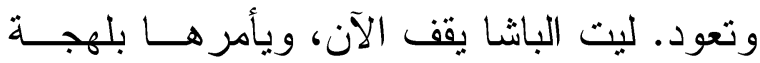
قاطعة أن تقوم لترتدي شيئًا فوق ما ترتديه، وتعد شــنطتها، ويرســلـل ســـائق ســـارته لينــزل

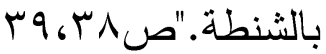
قد يوضح هذا المنولوج عدة دلالات:. أولاً: ما زالت شخصية الــزوج تصــور لنفسها قوتها، وذلك لأنه صور أن الباشـا "الجــــ" سبطلب منه أن يأخذها.

ثانيًا: عبث شخصية "عبده"، وبحثــه عــن

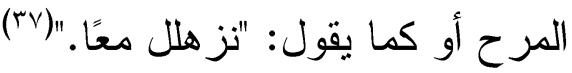

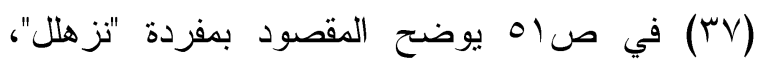
فيقول: "الزهللة كلمة اخترعها نايل لتجديد اللغة

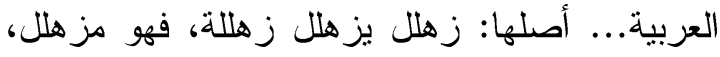
وهي مزهلة، وتكون حالة الزهللة حين تفاجئنا البهجات و الفرحات. فرحة المر اهقين بالقبلة الخاطفة 
حساسة من صغر ها. الموضوع عــايز رفــق. الأزمات بتحصل في كل بيت، وتمر بسلام بإذن الله. الله كفيل بدفع شر الولية أمها. كانت نايمـــة كالفتتة، لعنها الله، ولعن مَنْ أيقظها. هيَّ افتكرت دلوقتي إن عندها بنت، بعد كـلـ الســنين دي.. كلام كلام كلام.. يا خيبتك يا عبده."ص رغم أن ضعف الجد أمام الزوجـــة كـــان أمامه مما قد يجعله يُقدم على أن يتمرد، ويظهر جزءًا من هذا الحوار الداخلي في حوار خارجي مع الجد، لكنه لضعفه لم يستطع فعل هذا، بل لقد أعلن في حوار داخلي آخر مـــــأر اد أن يعلنـــهـ صر احة، فقال: "حادث نفسه بما يستحيل البــوح به: الرجل شاخ"ص بـ لأنه ضعف أمام حفيدته.

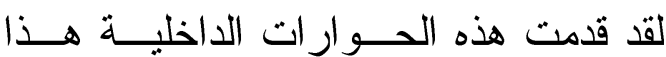
التعارض بين ما تقوله شخصية "عبده"، وبين ما تفكر فيه، لأن "ما تقوله الشخصــبة و الطريقــةم| التي تقوله بها يتركان انطباعًا قويَّا في القــارئ، ومن الممكن... أن تتعارض الأفكار مع الحوار؛ فمن شأن الشخصــبة أن تشــعر بشــيء مـــن

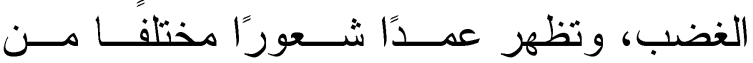
اللامبالاة، ولكن القـارئ ســـفترض عموضَّـا، وبغياب أي دليل آخر أن الانفعال الظاهر هــــو الصحبح." (r)( تأتي قوة الزوجة في مقابل ضعف الزوج، ويظهر ذلك من الحوارات الخارجية التي ســبق عرضها معه، ومن تعليقها على حوار خــارجي مع الجد بحوار داخلي، فقي حوارها مع جــدها

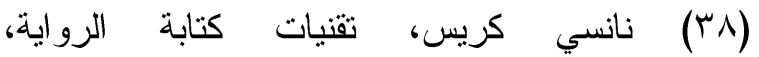

في هذا الحوار الداخلي قدم "عبده" ما لـــ

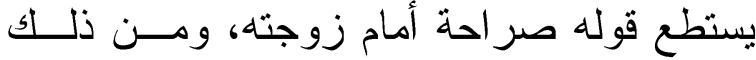
وصفها بالكلبة، وهنا يعلن قوة الجد التي يتوقـع منها أن يحطمه، ويحطم الزوجة، وهو لا ينفعل

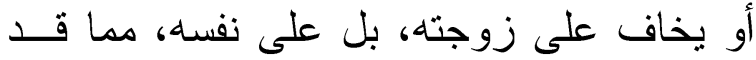
يبرز هذا الحوار جانبًا آخر من شخصية عبـده، و هو أنه لضعف شخصيته لا تهمه إهانة زوجته، لأن ما يريده منها فقط هي الشهوة الجنسية. و عندما بحدثه الباشا في حـــوار خــارجي

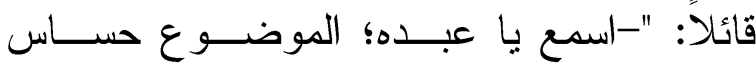
ومعقد. البنت متلخبطة.. و لازم برضها نر اعـي نفسيتها، ويمكن يكون مــن الحكمـــة معالجــة الموضوع ده برفق. حضرة سيدنا النبــي قــال: الرفق ما دخل في شيء إلا زانه، وما خرج من شيء إلا شانه."ص ع ك عندئذ يغيب عبده عن الجلســـة، ويوضــح شخصيته الضعيفة، ويبوح مرة أخــرى بمـــا لا لا يستطيع أن يبوح به أمام زوجته في حوار داخلي آخر، فيقول: "وهو يحادث نفسه: حلــو، حلـــو جدَّا.. الباشا بيحترمني دلوقتي. بس الاحتر ام ده مش ها يوصلنا لأي شيء.. طيــب، وبعــدين.. السنيورة/ الالوعة الكلبة بنت الشيطانة.. قامت وزبلت جدها دن غير أي احتر ام، و الباشا الكبير قاعد يكلمني رجلا لرجل عن الرفـق... وزانــهـ وشانه! يا فرحتي بالكلام."صץ ع، وفي حوار داخلي ثنالــث يعتــرف عبـــده

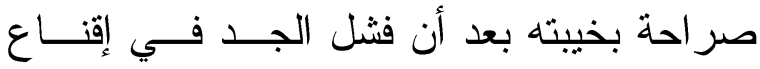
الزوجة بالرجوع إليه، فيقــول: "وآدي الباشـــا عمال يقول كلام عبيط: الموضوع حساس. البنت 
فالشخصية للقارئ عبارة عـن "تشــييد... مـــن إثار ات متنوعة ومتفرقة على طول النص. هذا التركيب أو إعادة التشييد يصفه بارت (باعتباره) جزءًا من عملية التسمية التي في رأيه متر ادفــة

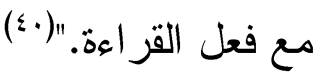
ع - ا- أزمة الشخصية: أو لاً: أزمة الزوج "عبده":

يبدأ الحدث الروائي بشخصية "عبده"، وهو بمفرده على درجات السلم لبيــــ ذي طــابقين، وفيه يُقدِّم من حوار داخلي ما قد يفيــد عيشــــه لأزمة، بل إن الجملة الأولى قد تفيد هذه الأزمة، فيقول لنفسه: "آخرتها إيه يا عبده يا غلبان." وفي صالا، ومن حوار داخلي آخر لعبده يوضـح أن الأزمة كبيزة لدرجة أنه يشــعر أنـــه ميت، وهو حي، فيقول: "إييه يا عبده يا مخلول. لماذا ترعدك هذه الخو اطر و الأفكــار .. هــــ.. مشغول بما سيحدث عندما تموت! إنك الآن ميت

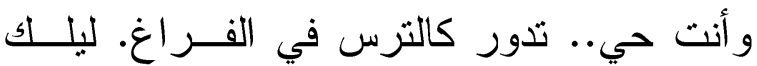
كئيب ونهارك.. لا أحد يهتم بك يا مسكين، مــع أنك لم تقصر في شيء.. طيب الصبر عمونــا طيب ومطلوب. قد تتصلح الأمور الليلة، وتكون آخرتها حلوة."

في صع (، يقدم لنا السارد نوع الأزمسـة التي تجعل شخصية ما تشعر أنها ميتة، وهـي حية، والتي تتلخص في علاقة عبــده المتــوتزة بزوجته، و التي بسببها لم تحدث بينهما أي علاقة ( • ؛) شلوميت ريمون كنعان، التخييل القصصي الثعرية

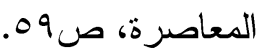

قالت هذه العبارة: "أبدًا يا جدو. كان عندي شوية أسئلة، و ماما بتجاوبني عليها." فكان وقع كلمة "ماما" على الجد أن أحسس "بجيش من عقارب... وبآلاف من أفاع" تتوغـلـ وتدب داخله، وشعرت الزوجة بوقع الكلمة على جدها، فقالت في حوار داخلي: "إذا كانت الكلمة قد أزعجته بظاهر حروفها على هذا النحو، فماذا لو عرف أن ماما هي أحد الأســماء الخمســين المقدسة التي خلعها أهل سومر على الأم العظيمة و الربة الأولى ننخرساج(rq")، فكانو ا يبتهلون إليها بها، ثم انتقل الاسم الإلهي إلى البابليين ليصـلـ من بعدهم إلى كلى لغات البثــر، اســـًا لكـلـل

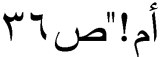

وهو ما قد يشير إلى أن الزوجة لم تخــف من الجد، فهي لم تحاول في حوار ها الداخلي أن تبحث عن كلمات قد تخفف بها من وقع كلمة "أم" على جدها بل تركته في أحاسيســه، و انشـــلت بمخاطبة القارئ لتعرض له ثقافتهــا ومســتو اها الفكري، ولتعرض معنى القداسة لمفردة "أم" من خلال البحث عنها في الأساطير السومرية التي تؤمن بالربة الأولى، و انتقالها من ســومر إلـى لـى باقي بقاع الأرض.

لقد نجحت الحوار ات الداخلية في توضــيح هذا الضعف من الزوج وهذه القوة من الزوجة،

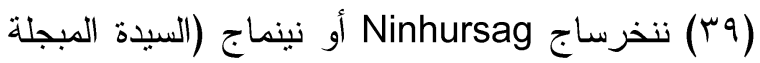
أو الأم الأرض الأصلية)، وهي ترتبط في الفكر

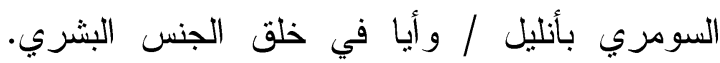

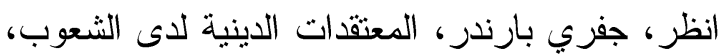


غيرها من علاقة الرجل بالمر أة. كما أن الفعـل "استلم" قد يبين أن الرجل لا ينظر إلى المر أة إلا

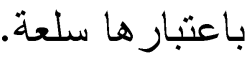
لكن ما ظُلل قد يوضح لنا أن المرأة هـي هـي التي تتحكم في هذه العملية، وليس الرجل كمــــا أر ادت له أن يعتقد، و هذا ما يوضحه لنا التشبيه "كخبيئة صادفت نابش قبور تعيس" الذي يجعلنا نزعم أن المرأة هي التي تفترس الرجل.

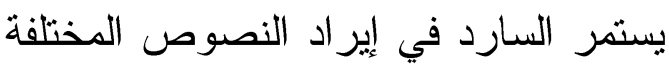
داخل النص الروائي، ليوضح بها أن شخصـية

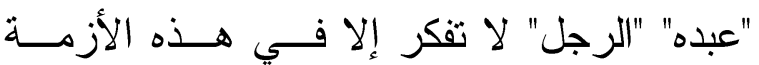

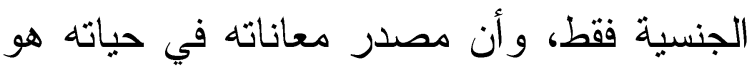
امتتاع زوجته عنها، وضعفه أمامها، وييرز ذلك ونكانه في عدة حوار ات داخلية موزعة على صــفحات

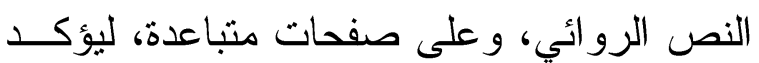

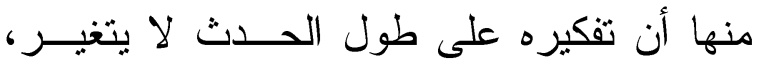
فالأزمة عنده جنسية حسية، ونظرته للمر أة تتعلق طول بهذا الجانب الحيو اني. ومن هــذه النصــوص مــــا نجــده فــي

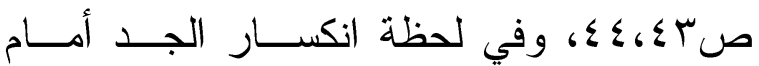
الزوجة، لا يجد "عبده" في هذا الانكسار إلا أنـــهـ

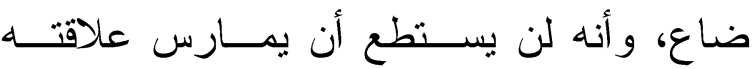
بزوجته. يقول: "أنا ضعت! كل حاجة ضاعت.

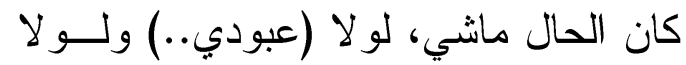

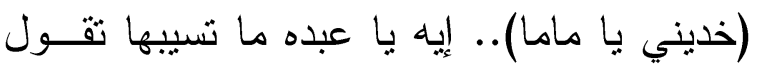

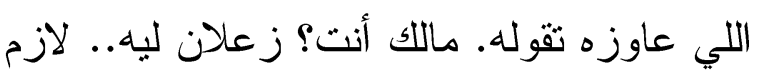
تعمل مشكلة، ما كانت عريانة تحنكا.. الكلبــة." لأن الزوجة كانت في لحظـــة مـن اللحظــات

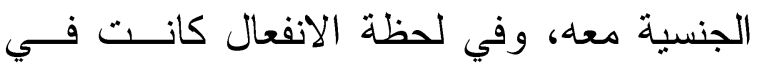

جنسية منذ سبعة وأربعين يومًا، ويحــد ميعـاد آخر لقاء جنسي بأنه كان قبيل الفجر ، وقد يقــدم هذا التحديد الزمني الدقيق من الشخصــية أنهــا

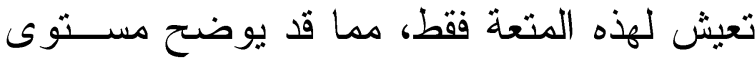
تفكيرها الباحث عن اللذة الحسية دون غيرهــا. يقول: "احتقن صوته، وارتطمت كلماتـــه بهـــا الجدار المنيع، الذي سرعان ما ارتفع في عينيها

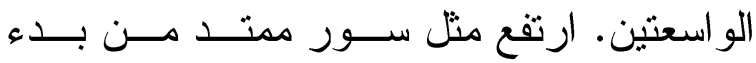

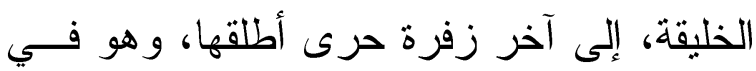
حضنها المتجرد، إلا من طغيان رغبتها المتأججة الطامحة إلى الإتاحة و المنح. كانت تلأك المــرة الأخيرة قبل سبعة و أربعين يومًا قبيل الفجر ." الفاله

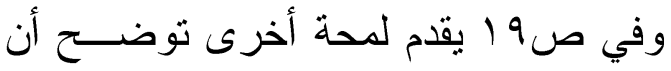
هذه العلاقة الجنسية لا يتحكم فيها الرجل، فيرى

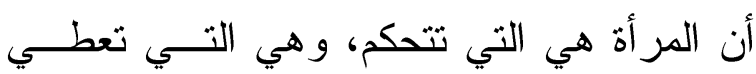
الرجل حقه الجنسي، كما أنها وحدها القادرة على وهي المنع، فيقول: "مضىى وقت طويــلـل منــــ آخــر استسلام. وقت طويل منذ آخر مرة استلم فيهـ جسمها الذائب بين ذر اعيه لينتشى بخمره إلى حد المجون، إلى حد النهم اللاأخلاقي، نهم البدائيين المحرومين. بلت له ليلتها باستسلامها العساري

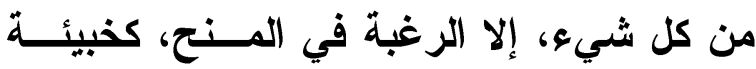
صادفت نابش قبور تعيس." يقدم لنا هذا النص ما يفيد هذا التحكم مسن لـن لئن المر أة في الرجل، فما وُضع تحته خط قد يفيد أن

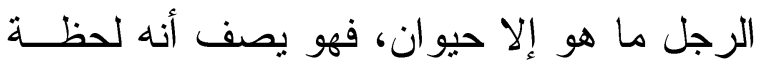
استلامه جسدها تعامل معها بالنهم اللاأخلاقة إلـي،

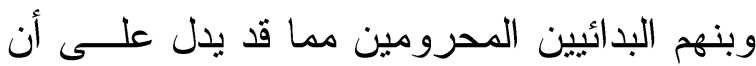
تفكيره كله ينصب على هذه العملية الجنسية دون 
أكد السارد هذه الشهوة الجنسية من "عبده" عندما قدم وصف الزوجة من تبئيره، فوجده في هذا الوصف لا يركز إلا على الأوصاف المادية الجنسية. يقول في صها ا: "لاحقهــا بناظريــــ مشدورهًا. خصــرها بـــيع، الثــوب الســماوي الفضفاض القصير بشف اللون الكحلي لملابسها الاخلية، وما ملابسها الداخلية إلا قطعة و احــدة ذات جناحين محلقين بردفيها، يمسكهما شريطان لامعان بلتصقان بإحكام بجانبيها.. النسيج الكحلي

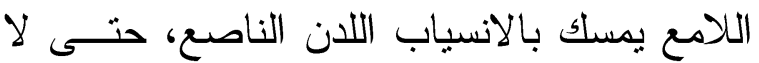
ينفلت! ليتها تخلع الثوب السماوي المشف، ليرى ما يضطرم تحته مسـن صــراع بــين اللامــع و الناصع، مع حركة ردفيها الرزينة.. و لابــــ أن النصوع سيغلب في النهايـــة، وتتفلــــ اللدونــــة العاجية الثهية من حصار ها. غاص في نفسه، هيجـــه التـــوق وفركــــ الشوق.. هو محبوس عنها بها، وجسمها محبوس عنه بأشرطة داخلية لامعة، وقطعة مــن نســيج كحلي تكاد تشف ما تحتها. لقد شفه الوجد.. فإلى منى سيدوم هذا الحبس!"

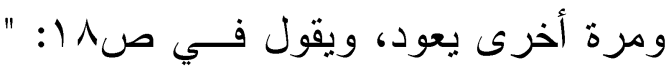
أراح عينيه على جدائل شعر ها المتهدِّلة خصلاته القوية، على كتفيها. انزلقت عيناه نحو اســــارة كتفها اليمنى، ماذا لو اقترب منهـــا الآن، ولــثم نقطة انحدار شمس الكتف البديع المنساب إلـى دفء الإبط؟ يا الله! من أية مادة سماوية خلقــ

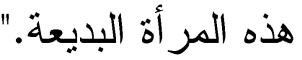
جعل السارد الرؤية و الإحساس من "عبده" لأنه أر اد أن يصور ما تريــده شخصــيته مــن
حوار داخلي توضتح به أن الرجال كلهم ســـواء، وأن "عبده" الزوج ما هو إلا رجل ككل الرجال، وأن المر أة هي مَنْ تمتلك القدسية، فتخاطب أمها في هذا الحوار الداخلي قائلة: "أتراني في هــــه اللحظة، تلك الأنثى في ذاتها التي حكيت عنهــا، وما هو إلا واحدٌ من الرجال، لا أكثر و لا أقل...

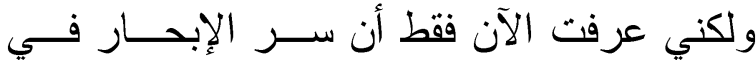
الأنوثة قد بكون بمجداف أي رجل، وعرفت أن النقطة/ السر إنما هي بداخلي أنا، وعرفت الدور العلوي حين سمعت صلصلة الجرس بأعمــاقي.

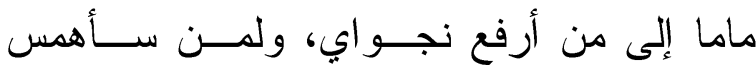
بأسراري، وهذا الرجل الذي فوقي، تحتي، وبيننا هاوية عصور سحيقة." تخنم الزوجة هذا الحوار الداخلي، وهي في لحظة الجنس مع الزوج بــأن تنادي على أمها قائلة: "ماما خديني"، وهنا ينهي "عبده" اللحظة الجنسية معها لأنها "شــعر أنهــــا انفلتتا من شفتيها، ليدلاه على تفاهتــه، وعلـى

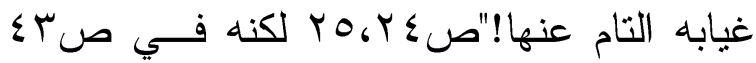
يعاتب نفسه على إنهائه للعلاقة الجنسية، فكأنــهـ يقر في هذا المنولوج بهذه التفاهة التي ســبق أن رفضها حال مناداتها لأمها، لأن المهر عنده أنها كانت عارية تحته. وفي صبح \ لا يهم "عبده" أن زوجته ملت منه، بقدر ما يهمه أن يشبع رغبته الجنسية منها، فيقول في حوار داخلي: "لعلها ملت الحياة معي. وليكن هذا لا يبرر نأيها عني. الملل وارد بــين المتزوجين. هي حالة عابرة... بعد أيام ستصفو،

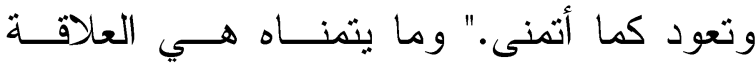
الجنسية دون العلاقات المعنوية. 
"عبده"، وير اه مظلاومًا مـــع زوجــة لا تعطيـــهـ حقوقه، و أنها المسئولة عن ضعفه، فيقــول فــي حوار داخلي: "حتى بخور الهيمان الذي يطـيح بر أسي، لم يجد معها نفعَّا لــلآن. حتــى دلال

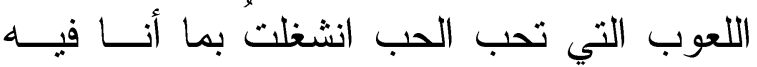
عنها، ولم أمد لها خيطًا، أو أمد للأمر بموعـــ

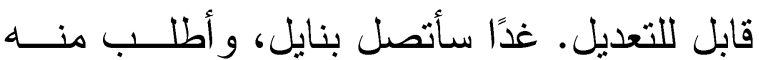
هاتف دلال، و أسأله عن مفاتيح جسمها، و الهدايا التي تحبها.. يا سلام عليك يا "عبده"، تفكر الآن فيما سوف تفعله غدًا.. الآن! يا أخي فكر فيمــا

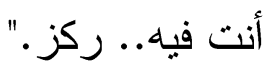
بخور الهيمان هو البخور الذي أعطاه إياه صديقه نايل موضحًا له أن "البنــات يفضــلنها

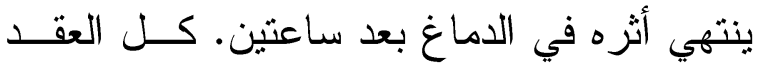
التي بينكما ستتفك خلال الساعتين."ص Vله وذلك حتى يغتصب زوجته التي تمتتع عنه عندما تلعب بر أسها هذا البخور، وهنا عندما لم يؤدِ البخــور دوره في الإطاحة بر أس الزوجة، بعد أن أطاحت بر أسه، لم يكن أمام "عبده" إلا التفكير فــي دلال اللعوب صديقة نائل أو لنقل فتاة الحب؛ مما قــــ يعمق دلالة أن "عبده" لا يريد إلا هذا الإشــباع لرغبته الجنسية إما عن طريق اغتصاب زوجته ببخور الهيمان، أو عن طريــق العلاقــة غيــر الشرعية مع فتيات الحب "دلال". وفي آخر حوارات الرواية الداخلية، والذي

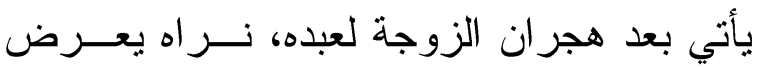
لقدرته المادية و الجنسية، ونر اه بعلــن رفضـــه الزواج، ويفضل هذه المعاشــرة دون الــزواج،
زوجته، فالشخصية تنظر إلى الآخر إلى ما تريد

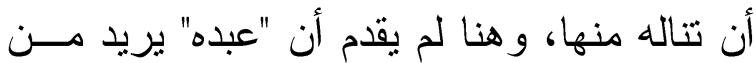
زوجته أي معاني معنوية، فكل ما بحث عنه هو المعاني الحسية، حتى عندما تعجب في قوله "با الله! من أي مادة سماوية خلقـــ هـــه المــر أة البديعة" كان التعجب من جمالها، ولهذا يتبع هذا

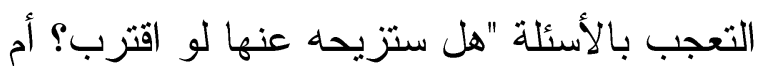
ستتركه يجتاحها، مدفوعًا بغيّه نحــو غاياتــه؟

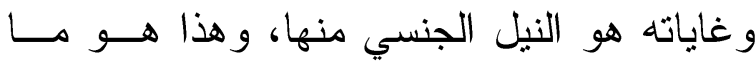
ظهر في هذا النص السردي الذي قد "يقدم أحيانًا إثار ات بالغة التشويق، كما لو أن الخطاب يبطئ خطاه، وقد يتوقف نهائَّا كما لو أن المؤلف يريد أن يقول: "عليك أنت أن تستمر"."(1) يريد السارد من القارئ ألا يتعاطف مــع

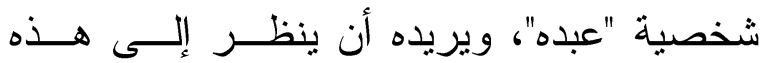
الثخصية على أنها شخصية حيو انية تبحث عما يرضي لذتها الحسية فقط، لأنها شخصية تميـلـل أفعالها إلى الأفعال الاعتيادية التي "تميل... إلى إظهار المظهر الثابت و الســكوني للشخصــية، وكثيرًا ما تكون لها آثار هزلية أو ساخرة، مثلاً حين تتعلق شخصية ما بعادات قديمة في وضــع يجعلها غير ملائمة."(r)

فيقدم لنا في صع م ما قد يؤكد هذا البحث المستمر عن الشهوة حتى، ولو لـــ تكـنـ مــع زوجته، على أساس أن القارئ قد يتعاطف مـــع

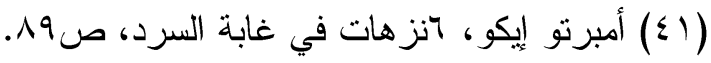
(2) شلوميت ريمون كنعان، التخييل القصصي الثعرية المعاصرة، صع 9. 
إلى حضرثي لتحرق بخورك؟ لا أظن. وعيــاك

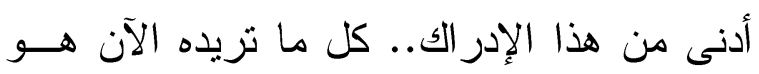

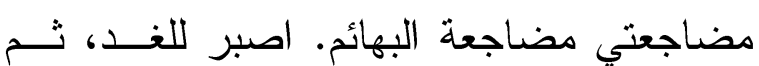
عليك بالبحث عن بهيمة تتكحها وتتكحك. بهيمة

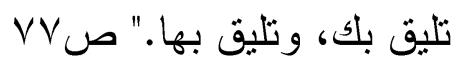
هذا هو الفرق بين "عبده" الزوج و الزوجة في لحظة واحدة. هــو يبحــث عـنـ الإشــباع الجنسي، وهي تدرك غرضه، وترفضـــه لأنهــا تعرف أنه يريد منها أن يضــاجعها مضـــاجعة البهائُ. ولذلك تخنت هذه الفقرة بالطلــب غيــر المعلن منها له أن يبحث عن بهيمة أخرى مــن الغد. بهيمة تليق به، ويليق بها. في هذه الفقرة نستطيع أن نلمح هذه الأزمة التي تعيشها شخصية الزوجة، وهي البحث عن قداسة المر أة، وذلك في: ـ ـ مناداتها لعبده بــ"عبد" بحذف الهــاء،

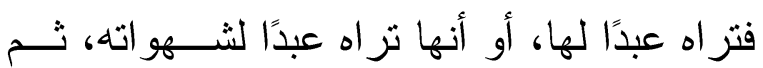

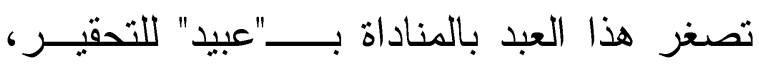
فكأنها خصصت العبودية لشهوته دون غيرها. r_ من هنا كانت المناداة الثالثة بـــــ"ائها الضئيل"، لتأكيد معنى الحقارة التي وضحتها في التصغير السابق في "عبيد". و هو ما يوضح رؤية

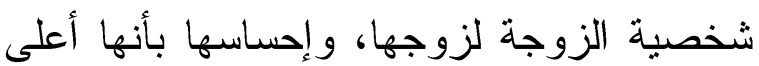
منه، لأن العبودية للشهوة هي تحقير من الإنسان لنفسـه.

بـ إحساس الزوجة بمعنى القداسة، و الذي ظهر في قولها: "كل ما تحرقه من بخور علــى لـ إنى مذبحي المقدس." وقولها: "أثر الك أدركت أخبــرًا

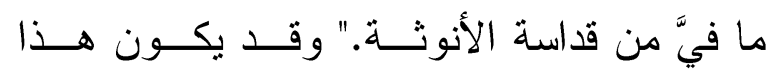

"لن يأتي بعد اليوم رسائل. رسائل بــدون الر اء تكون سائل و السائل هو الشحات. أنا لست شحاتًا. عندي هذا البيت، و عندي وظيفة جيــدة وقدرة جنسية ومؤدب.. سأجلب إلى هذا السرير كل نساء الأرض. لن أضاجعهن إلا على هـــا السرير الذي نامت هي عليه سبع سنين. لن أشبع منهن، ولن يشبعو ا مني، ولن أنزوج ثانية أبــدًا، فالزواج حماقة لا يجب أن تقتــرف مـــرتين..

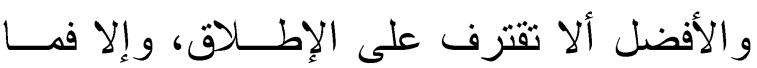
يدريني إن نزوجت ثانية، أنتي سأقضــي ســبع

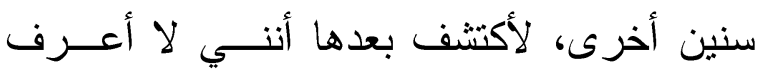
المر أة التي تزوجتها، أو أفاجأ بأن لها أمَّا ترسل لهل

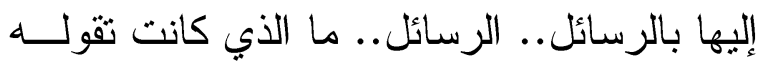
فيها لابنتها هذه المر أة الكافرة؟"صوبه 99 ثانيًا: أزمة الزوجة "نو اعم": على عكس الزوج الذي يعيش أزمة حسية

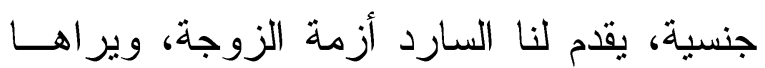
أزمة معنوية بالدرجة الأولـى. تتعلــق أزمسـة

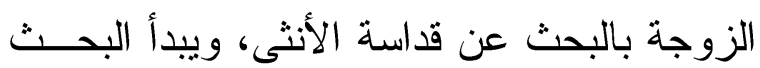
هنا من رأي الزوجة في بخور الهيمــان الـذي لـي سبق عرضه في أزمة "عبده"، وبحثه عن لحظة اغتصاب زوجته، فالزوجة في هذه اللحظة تقول لنفسها: "كيف هداك تفكيرك إليها؟ كيف عرفــت أن ذهني مكدود وفكـري مــزدحم، و لا شــيء سيهدِّئُ من روعي ومن عو اصفي، مثـلـ هــــه

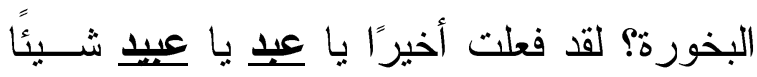

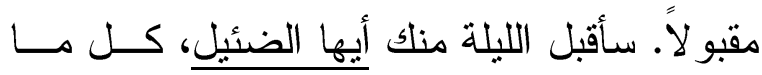
تحرقه من بخور على مذبحي المقدس. أتــر الك

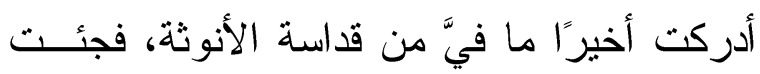


و العمليات النفسية لديها -ـون النكلم بذلك علــى نحو كلي أو جزئي- وذلك في اللحظة التي توجد فيها هذه العمليات فــي المســتويات المختلفـــة للانضباط الواعي قبل أن تتشكل للتعبير عنهــا

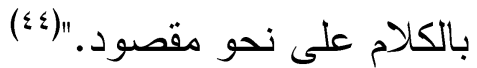
لكن يجب الإشارة هنا إلى أنه لــيس كـلـل حوار داخلي تيار وعي، وذللك لأن الكاتب فـي تيار الوعي "يقدم... الأفكار (الرؤى و المشـــاعر) كما تتكون بالتدريج في وعي الشخصـيات."(0؛ بينما قد توجد حوار ات داخليــة يلخــص فيهــا السارد استرجاعات خارجية تتذكر ها الشخصية، فتعرضها للقـارئ، وتتركــهـ يقـارن الأمسـس بالحاضر ، ومثاله في رواية "ظل الأفهـى" هـــا الاسترجاع من شخصية عبده، فبعــــ أن نادتــهـ الزوجة بــعبودي." يسترجع "عبــده" بحـــوار

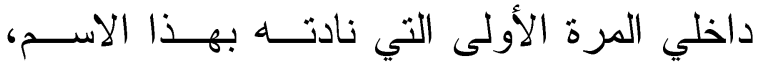

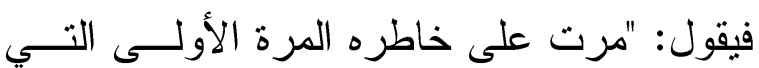
نادته بهذا الاسم. لما سألها حينهـــا، قالــت : إن

(§) روبرت همفري، تيار الوعي في الرواية الحديثة،

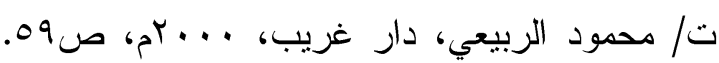

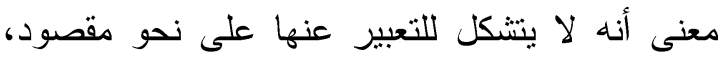

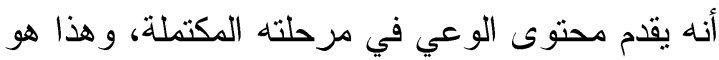
الفرق الذي يفصل بين المنولوج الداخلي، وبين المنولوج الدر امي ومناجاة النفس على خشبة المسرح. (0) مجموعة من النقاد، نظرية السرد من وجهة النظر

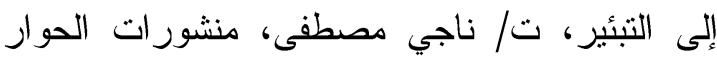

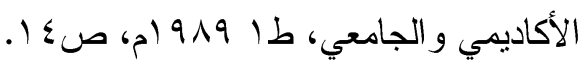

الإحساس بمعنى القداسة هو الذي يجعلها تزفض أن تفكير زوجها في المضاجعة، وإن أوضحت أنها لا تز فض المضاجعة بعامة، بل تــرفض فكــرة المضاجعة الحيو انية (مضاجعة البهائم). ولقد عبرت سيمون دي بوفوار عن هــذا المعنى عندما رأت أن "المر أة تعطي نفسها، أما الرجل فيزداد بها. هذا ما كتبتــهـ ســيمون دي بوفوار ... عن الحب. كما كتبت صفحات أخرى عن التمايز الجنسي في الأدوار/ العشقية، وعن الدلالة غير المتكافئة لاى كل من الجنسين، فعند الذكور لا يظهـر الحــب (باعتبــاره) رســالة وتصوف ومثال حياة قــادر علــى امتصــاص الوجود بأكمله؛ فهو بالأحرى مثنـال عـــارض، وليس سببًا حصريَّا للحياة. بينما يختلف ســلوك

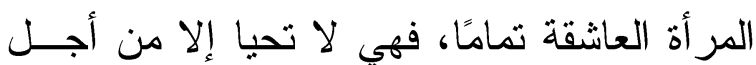
الحب، و لا تفكر إلا في الحب؛ ذلك أن حياتهــا كلها تشيد بناء على الحبيب، الذي يمثل الهـدف الأساسي و الوحيد لوجودها."("؟) قد ينظر إلى الروايات التــي تعتمـــد فــي تقنياتها على أسلوب الحوار الداخلي، باعتبار هــــا روايات تيار وعي، وذلك باعتبــار أن الحــوار بـار الداخلي قد تعبر فيه الشخصــية عــن واقعهــا، خالطة فيه بين الماضـي و الحاضــر و المســتقبل

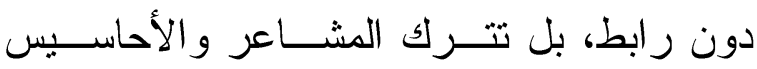
تتدفق، فتجسد أعماق النفس بكــلـ اضـــر اباتها و آمالها. إننا نقدم "المحتوى النفسي للشخصــية، (بَ) جيل ليبوفيتسكي، المرأة الثالثة: ديمومة الأنثوي وثورته، ت/ دينا مندور، م/ جمال شحيد، المركز

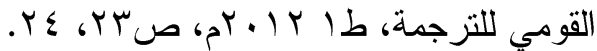


أر اد بهما أن يعقد القارئ مقارنة بــين ثقافتهــا، وثقافة زوجها الضحلة ليعمق بذلك هذه القدســية التي يريد تأكيدها للزوجة.

فقي صه VO عندما يعرض السارد لبخورة

الروقان، يتزك السارد العليم شخصية الزوجــة تقوم بدور السارد لتعرض مشاعر ها المضطربة، لترون وتلخص للقارئ ما تريد فعله بعد ذلك، و هنا يقوم

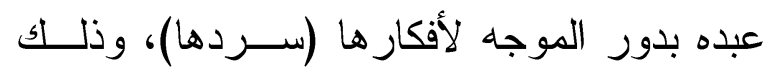
عندما يحدثها بين حين، و آخر بجملة أو بعبارة.

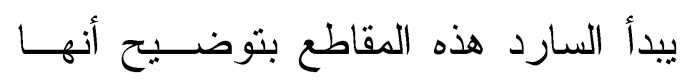

نجوى نفس من الزوجة، فقبل أن تلعب البخورة

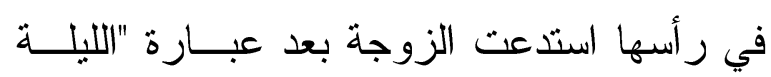

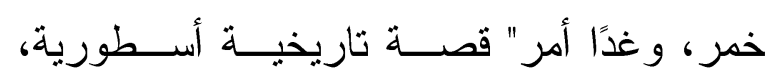
فيقول: "وهي هائمــة فــي ملكوتهــــا البــاطن، ونجو اها: ماذا يريد مني هذا العبده؟ لا بأس لــو هو قضيت معه بقية الليلة هنا. هي على أي حــال، ليلتي الأخيرة معه، فلا بأس لو استرخيث قليلاً.

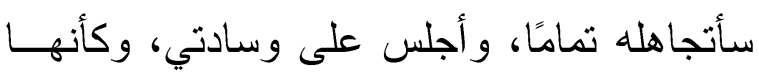

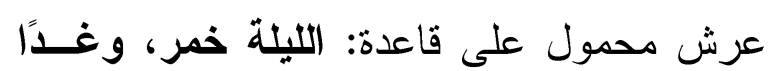

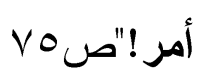

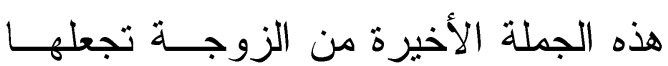
تدخل في أسلوب التداعي لتستدعي معلوماتهــا، ولتستدعي ما قالته أمها عن هذه المقولة، فتكون

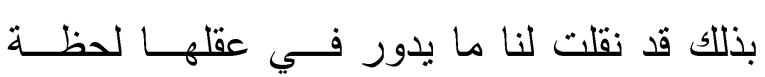
بلحظة، فتقول:

"الليلة خمر ، وغدًا أمر . أين قــر أث هــــه

العبارة؟ أين؟.. أهي عبارة امرئ القـيس التـي وني

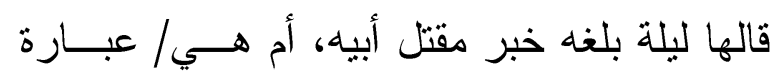

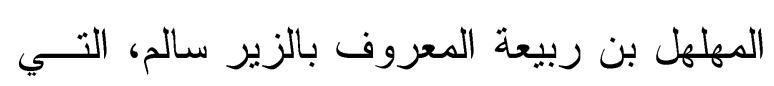

اسمه الجديد هذا، تدليل لكلمة/ عبده التي يناديـــه الناس بها. ثم أضافت بدلال ويسر : عبــــــــنْ

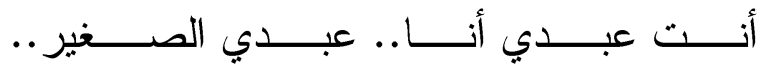

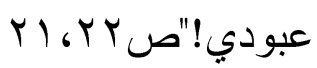
من هنا يزعم البحث أنه بما أن تيار الوعي يُعرَّف بأنه "نوع من القصص يركز فيه أساسَــا

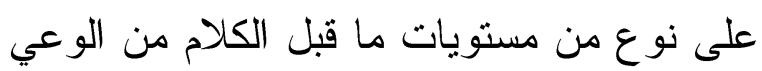

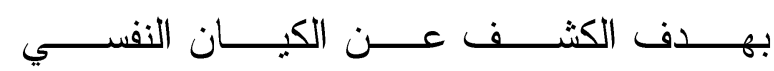
للشخصيات."("ٓ؛) فإن معظم الحوارات الداخليــة في رواية "ظل الأفعى" تتتمي لتيار الوعي، وهو ما ظهر في الاستشهادات التي سبق عرضها في تقديم الشخصية وأزمتها( أ). وسيركز البحث في هذه الحوارات على حـــوارين مــن الحـــوارات الداخلية للزوجة تبرز بها حالتها النفسية لحظـــة الوقوع تحت تأثير بخورة الروقان التي أتى بها

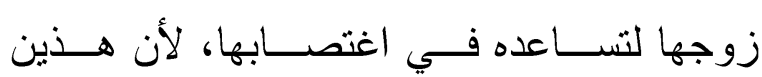
الحوارين يبرزان ثقافة الزوجة، وكأن الكاتـبـ لـابـ (T؟) روبرت همفري، تيار الوعي في الرواية الحديثة،

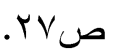
(§V) لم يجد البحث إلا حوارين داخليين يقومان بدور

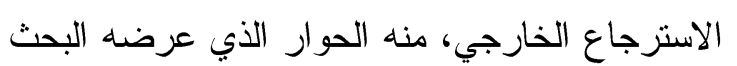
في المنن، وحوار آخر يسترجع فيه عبده لحظة من من الحنه

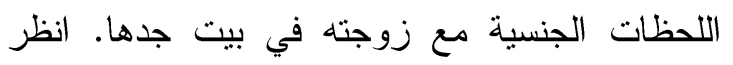

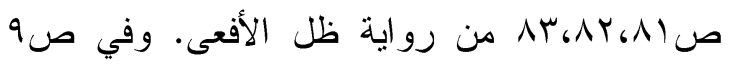

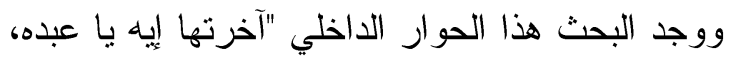

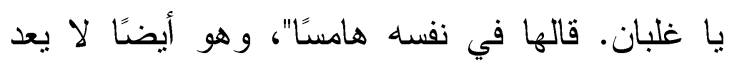

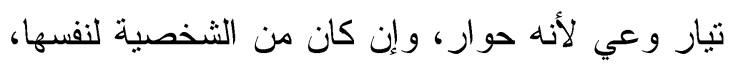

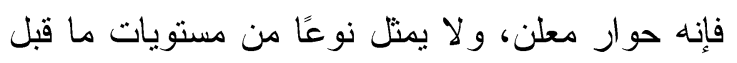

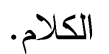


فتختم الزوجة هذا المنولوج بالرجوع إلى

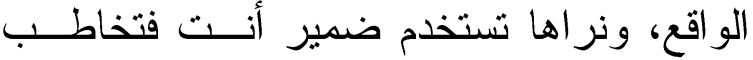

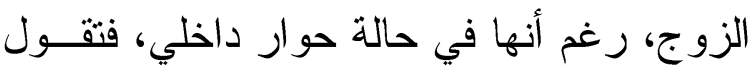
الزوجة: "ما لي الآن، وهذا التاريخ البعيد.. هل

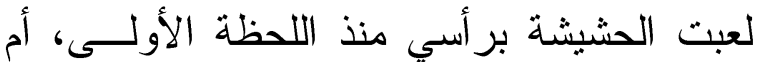
تر اني كنت مستعدة لها من قبل دخول الغرفــة.

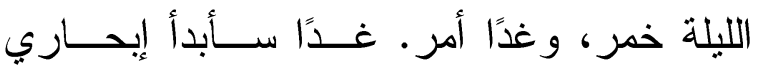
الطويل، هجرت إلى ذاتي، لحاقي بماما.. مامسـا

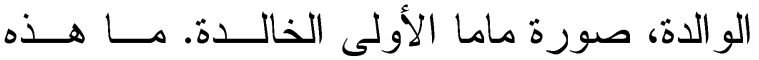

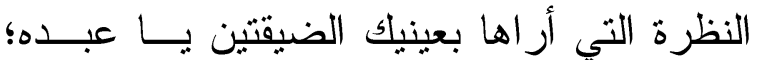
نظرة فأر محصور .. لا بل نظرة قطة ضــالة، لحقت بمائدة فقيرة على طرف رصيف لتتســول

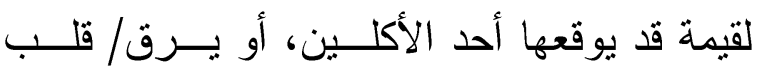

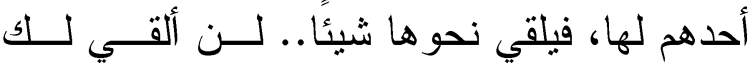
بشيء الليلة. يكفيك أن تتأملني هكذا من بعيـــ. سأدع شهوتك تشويك، ولن ألهب جسدي بحمحة

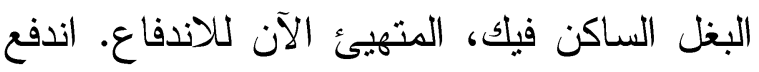

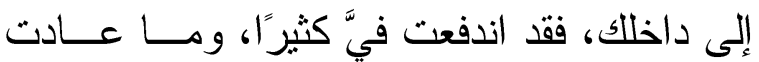
أرضي البيضاء تحتمل اتساخ حوافرك. ابحــث

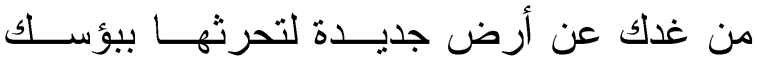
الأزلي، ثم ألقي بجوفها بذورك المعطوبة، حتى

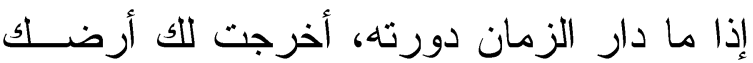

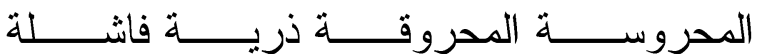

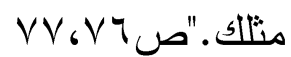

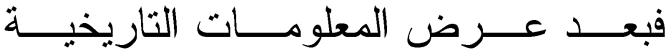

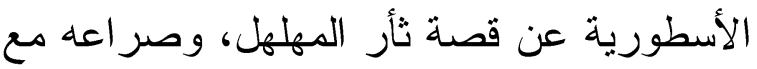
قبيلة بكر، تتنقل الزوجة لعرض وجهة نظرهـــا في شهو انية زوجها، وتر اها شهوة حيو انية بدليل هذه الكنايات "بحمحمة البغل الساكن فيك"- "وما
قالها ليلة مقتل أخيه كليب، ثم شرب حتى الثمالة لآخر مرة، وقضى بقية عمــره يثـأر لأخبــه.

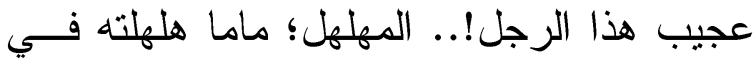
كتابها: أساطير الذكور المتأخرة. هو عندهم ثائر

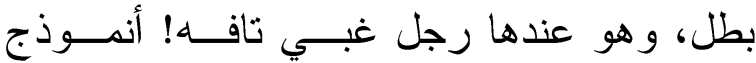
ذكوري نمطي، أضاع بإمعانه في القتل و الادعاء الأجوف بعدم الرضا الثأري، مجدًا وليدًا كانــــ قبيلته تظلب، وقبيلة أعدائه، و أبناء عمومته بكــر سيفخران به، ويقودان العرب.. كليب بن وائــلــ رسم الطريق، و المهلهل أضاعه. كليب خـاض لهـاض حربًا لأن رجلاً لطم أخته، فانتصر • و المهاهـلـل ظل يثأر لكليب ثلاثة وعشرين عامًا، لم ينتصر

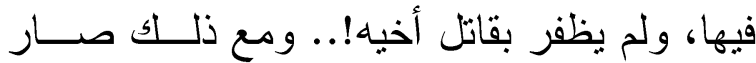
عند الناس بطلاً. لولا الإسلام لأكلت تغلب النـاس. قــــل

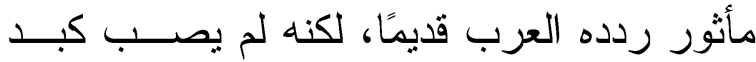

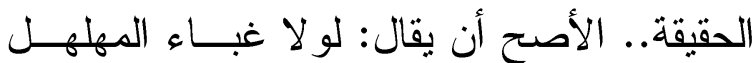
لظهرت تغلب، وقادت كل العرب!"صT،VO بعد هذا تتساءل ما لها وهذه القصة، وكأن الكاتب هنا يحيلنا إلى أن تداعي الحواس عنــــها

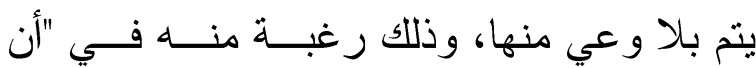
يتمكن من تقديم الوعي على نحو و اقعـي عـن لـن طريق إدر الك سمات خصوصيته (عدم الترابطعدم الاستمر ار - الإيحاءات الخاصة)، كمـــا أن عليه أن يتمكن من توصيل شيء/ ما للقارئ من التهرئ

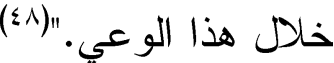

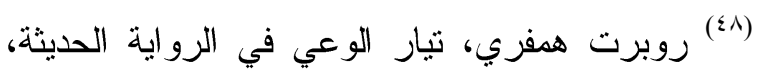

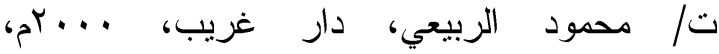
ص ص n 
و هذا الضمير "أنتث"، "إنما هـــو مجــرد قنــــاع للمنولوج الذي يستخدم ضمير المتكلم"(9؛) لتذخل هو بعد ذلك باستخدام لغة مجازية لعرض رغبتهــا في الرجوع إلى معنى الأنثى المطدــور عبــر

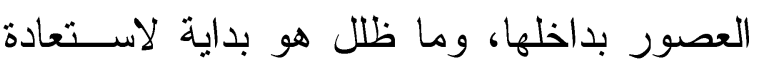
تيار من الوعي الداخلي للزوجة لتظهر قدسـية

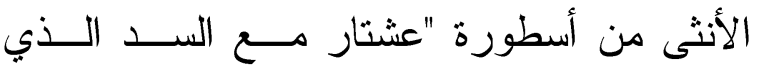

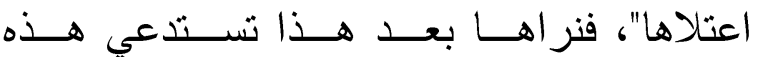

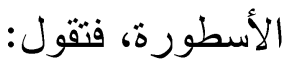
"عسى أسد الغابة الهصـــور أن يــأتيني، فيعتليني: آه يا عشتار .. كيف شعرت بالأسد حين اعتلاك؟ وكيف اكتفيت بأسد واحد؟ هــلـ يهــز أعماق الأنوثة الكامنة ور اء عريي إذا ما اكتمل كل أسود الأرض؟ لا و لا كل الذكور التي تسعى إن فوق الأرض... ولا الأرض بمن عليها. رحمـي الاولي

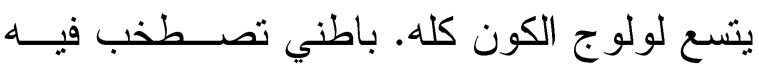

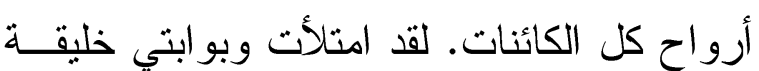
بانبثاق العالم منها، بإبراز كل الأحياء للوجود. آه أيتها الربة تعامة لقد عرفت الآن شعورك بهراوة مردوخ العتية، وهي تشقك نصفين، فتكون منهما

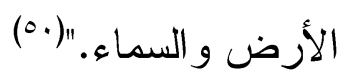

فلا تكتهي بذكر أسطورة "عشتار"، فنر اهـــا

تتهي هذا التداعي للشــعور بأســطورة تعامـــة ومردوخ، وقصة بدء الخلق، ليبرز هذه القدسية

(§) روبرت همفري، تيار الوعي في الرواية الحديثة، (10)

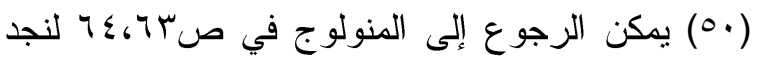

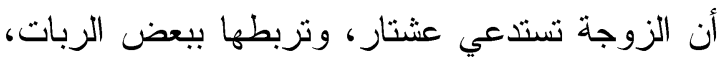

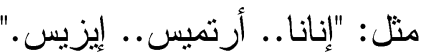

عادت أرضي البيضاء تحتمل اتساخ حو افرك""ابحث من غدك عــن أرض جديــدة لتحرثهــا

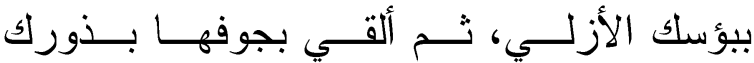
المعطوبة."- "أخرجت للك أرضـــك المحروســـة

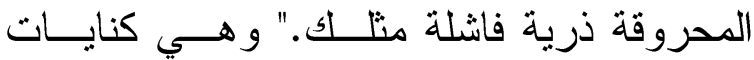
توضح هذه الحيوانية التي يعيشها "عبده" الزوج، وفي هذا الحوار الداخلي تضــرب علــى وتـــر الرحيل، وتعلنه صر احة.

وفي صو V وبعد حوار خارجي من عبــد

بجملة واحدة يقول فيها: "قربي مني يا حبينتي." تدخل الزوجة في منولوج لتعرض رأيهــا فيه، وتطلب منه الابتعاد عنها لأنها تعرف مـــا يريده منها، فتقول: "ابتعد عنـي، و إلا صـــارت ليلتك ليلاء. ما للك تتزحف نحوي منــذ دخلــــ الغرفة، ألدخلتني لتميلني.. هه! إلبك عني. دعني أتسلق خيوط الدخان، فقد أوشكت البخــورة أن يكتمل احتر اقها. قاعدة الهــرم الفــــواح، كــادت تتمحق تحت صفحة جمرتها الرقيقة. يصَّاعد من باطنها ثلاثة خيوط دخانية أثند قــوة وتــأثيرًا. دعني أراقب انتهاءها. اختفاءها. نوغلّ جمرتها فيها، وتبددها فيَّ. ابتعد و اتركني قلــلاً وحــدي.. وحــدي سأتصـاعد مع خيوط الاخان الأخيرة. أتســامى. أعلو من أرض الغرفة إلى سمائها من جــوارك إلى جوهري. دن تمددي إلى مددي الآتي مـنـ وحي الأنثى المطمور عبر العصور. لو لم تكن

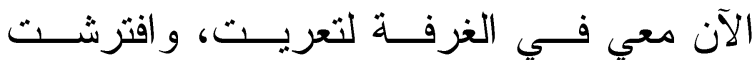
الأرض، و انفتحت." إلى هنا الضمير المســتخدم هو "أنت"، فكأنها في حالة حوار مـــع الــزورج، 
ـ ارتباط عنوان الرواية بايحائية الحــوار

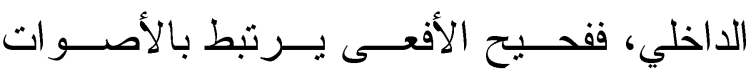

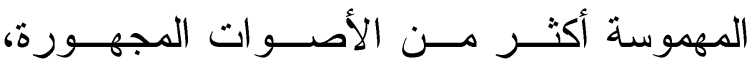
و الأصو ات المهموسة هي الغالبة على الرواية.

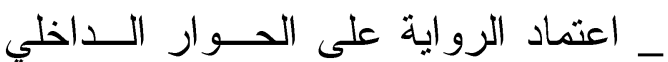

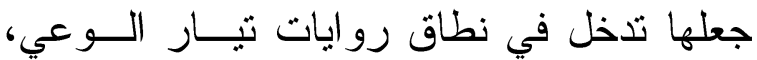
باعتبار أن الثخصية في الحوار الداخلي تعبــر عن و اقعها خالطة بــين الماضــي و الحاضــر و المستقبل من خلال مشاعر و أحاســيس تتـدفق وفي

$$
\text { دون رابط. }
$$

لقد طرحت الرواية انتصار ها للمر أة على

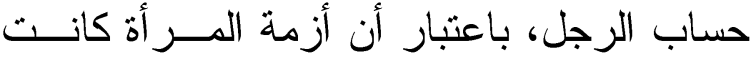
معنوية بالدرجة الأولى، وهو شعور ها بقسيتها؛ تلك القسية التي حاولت الزوجة تأكيد وجودهـــا منذ الحضار ات القديمة، بينما أزمة الزوج كانت مادية، وتعلقت بشيء و احد فقط، ألا وهو محاولة إثباع شهوته الجنسية و النيل من زوجته، ولــو وصل الأمر حد الاغتصاب. ووجدنا أن السارد

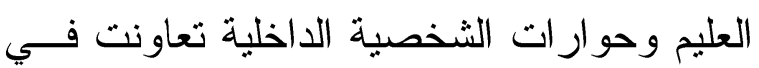
أن تقدم الزوجة في مستوى مـــادي واجتمـــاعي

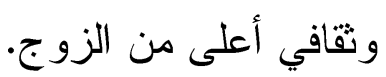

كان هذا التقديم دون أن نبحث خارج النص الأدبي، بل من خلال مناقثـــة العلاقــات بــين وظائف الوحدات السردية و الوصفية من السارد العليم ووظيفة الحوار الداخلي من الشخصــيتين الرئيستين، فـ"من الضروري إذن أن لا يغرب

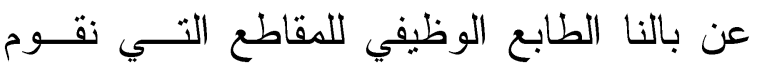

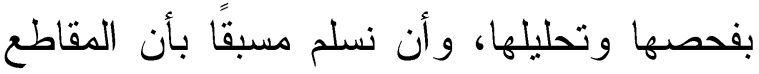

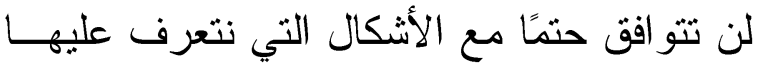

للأنثى من القدم، ولو عن طريـق الأســاطير، وذللك من خلال "العالم الداخلي للنشاط الــــهني الأي يجعل فيه من تلكك القيم قيمًا دراميــة... ولكي ينال الكاتب ثقة القارئ... كان على كاتب تيار الوعي أن يفعل شيئين: أ_ عليــهـ أن يقــدم النسيج الحقيقي للوعي. بـ وعليه أن بستخرج

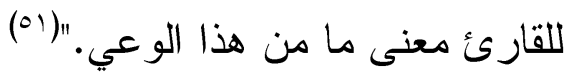
ومن دراسة الحوار الداخلي في رواية "ظل الأفعى" اتضح للبحث ما يلي:

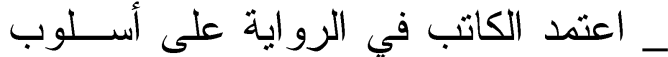
الحوار الداخلي دون الحوار الخارجي باعتبـــاره آلبة من آليات رسم الشخصيات. ـ اختار البحث من النظرية البنيوية الطابع

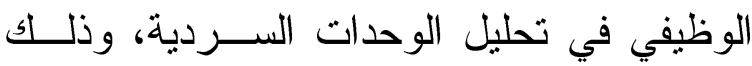
للكثف عن الوظيفة التي يقـوم بهـــا الحـــوار

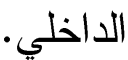
ـ جاءت الحوارات الداخلية للزوج أكثــر من حوارات الزوجة الداخلية، وذلك لأن أزمسـة

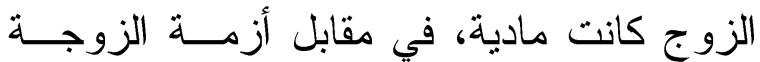
الروحية؛ وذلك باعتبار أن الثخص المادي ينكلم أكثر من الثخص الروحاني. ـ ـ استخدم الكاتب السارد العليم، وذلك لأنه أر اد أن يعـرض لوجهــة نظـــر الثخصــيتين الرئيستين، وبجانبهما يعرض لوجهة نظر السارد العليم من خلال تدخلاته، وتوجهه المباشر إلـى

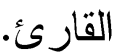

(10) روبرت همفري، تيار الوعي في الرواية الحديثة،

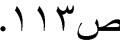


ب _ حميد لحمداني، بنية النص الســردي مــن منظور النقد الأدبي، المركز التقافي العربي، .

بـ سيز ا أحمد قاسم، بنـــاء الروايــة، دراســـة

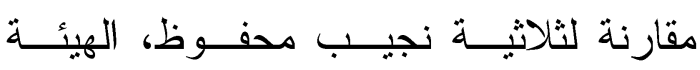
المصرية العامة للكتاب ع 9 ام. ع_ كمال أبو ديب، الرؤى المقنعة، نحو مــنهج بنيوي في دراسة الثعر الجــــاهلي، الهيئــة

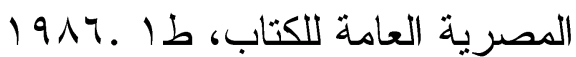
__ محمد برادة، الرواية العربية ورهان التجديد،

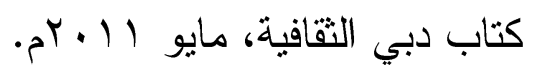
ج__يمنى العيد، الر اوي؛ الموقع و الثكل (دراسة في السرد الروائـي)، مؤسســـة الأبحــاث

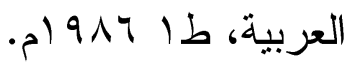
ثالثًا : المراجع المترجمهة: _ـ أمبرتو إيكو، بنزهات في غابــة الســرد، ت/سعيد بنكر اد، المركز التقافي العربي، طا . 0 ץ_ برنار فاليط، النص الروائي تقنيات ومناهج، ت/ رشيد بنحدو، المجلس الأعلى للتقافة.

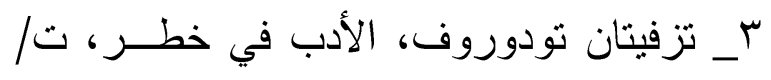
عبد الكبير الشرقاوي، دار توبقال المغــرب

$$
\text { ط }
$$

؟_ جفري بارندر، المعتة ــدات الدينيــة لــدى الشعوب، ت/ إمام عبد الفتاح إمام، سلسـلـة بـاهـ

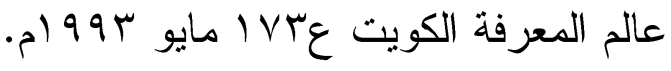
_ جون ليشته، خمسون مفكرًا أساسيًّا معاصرًا من البنيوية إلى ما بعد الحداثــة، ت/ فــاتن
عادة من خلال مختلف أجز اء الخطاب الســردي (أفعال - مشاهد- فقر ات- حوار ات- حـــــار ات

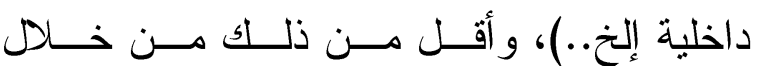
المستويات النفســية (ســلوكيات الشخصــياتمشاعر ها- نو اياها- حو افز ها- مبرر اتها)."(Or) وقد يؤكد هذا أن التحليل البنيوي للعلاقات بين الوحدات الداخلية لبنية النص قد تكون قادرة على أن تفهينا جزءًا من الواقع الذي تريد هــــه البنية أن تعبر عنها، فنحن إن "لم نكن قـادرين على فهم البنية فـي وجودهـــا الكلــي و إدر الك خصائصها الجوهرية، فسيكون مــن العبــث أن وئ نحاول فهم العلاقات التي تنشأ بينها، وبـين أي من الثروط التي تقع خارجها علــى محسـوري التز امن و التو الد ضمن البنية الاجتماعية."(or)

المصادروالمراجع أولًً: المصادر: يوسف زيدان، ظل الأفعى، دار الثــروق، طل $\cdot 4 \cdot 11$

\section{ثانيًا : المراجع العربية :} ' أنجيل بطرس سمعان، در اسات في الرواية

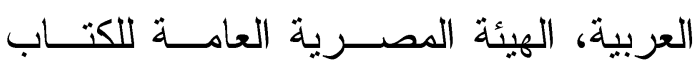
. $9 \wedge \mathrm{V}$ (Or) مجموعة من المؤلفين، طر ائق تحليل السرد الأدبي،

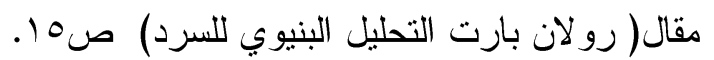

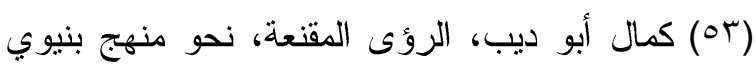
في دراسة الثعر الجاهلي، الهيئة المصرية العامة 
سا _ فلاديمير بــروب، مورفولوجيــا القصـــة وتحولات القصص العجيبة، ت/ عبد الكريم حسن - سميرة بن عمو، شــر اع للار اســات و النشر والتوزيع، طا 999 ام.

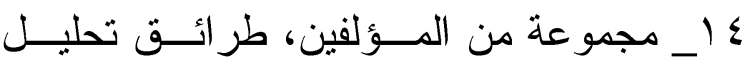
السرد الأدبي، ت/ حسن بحراوي، بشــير القمري منشورات اتحاد كتاب المغرب، طا $.0199 r$ 10 _ مجموعة من النقاد، نظرية الســرد مــن

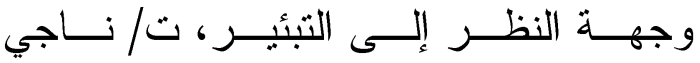
مصطفى، منشــور ات الحــوار الأكــاديمي و الجامعي، طا 919 ام. 1 _ ميشال بوتور، بحوث في الرواية الجديدة، ت/ فريد أنطونيوس، منشــورات عويــدات

$$
\text { بيزوت، طن } 919 \text { ام. }
$$

| _ IV نانسي كريس، تقنيات كتابة الروايـة، ت ت زينة جابر إدريس، الدار العربية للعلوم، طا

$$
.0+\cdot 9
$$

11 ـ ـ الاس مارتن، نظريات السرد الحديثة، ت/ حباة جاسم محمد، المجلس الأعلى

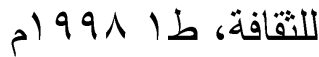

البستاني، المنظمة العربيــة للترجمــة، طـ اه

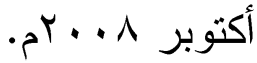

؟ _ جيز ار جينت، خطاب الحكاية، ت/ محمـــ المعتصم، عبد الجليل الأزدي، عمر حلـى، المجلس الأعلى للثقافة . ... بم. V_ جير الد برنس، المصطلح السردي، ت/ عابد خزندار، المجلس الأعلى للتقافة.

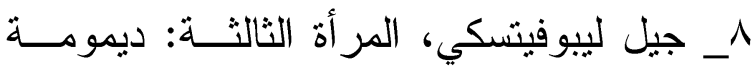
الأنثوي وثورته، ت/ دينا مندور، م/ جمــال

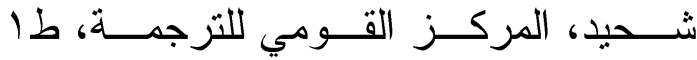
$\cdot 4 r \cdot 14$ 9 _ ديفيد لــودج، الفــن الروائـي، ت/مـــاهر البطوطي، المجلـس الأعلــى للتقافــة طا $r \cdot r$. • ــ روبرت همفري، تبار الوعي في الروايــة

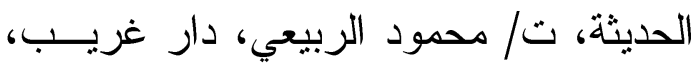
. • ـ روجر ب. هينكل، قر اءة الرواية مــدخل إلى تقنيات التفسير، ت/صــلاح رزق، دار

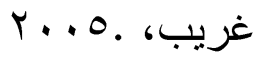
r 1 شلوميث ريمون كنعان، التخييل القصصي الشعرية المعاصرة، ت/ لحسن أحمامة، دار النقافة، ط (، 